\title{
NEW HEARING TEST ABOVE THRESHOLD AND ITS CLINICAL SIGNIFIC ANCE
}

\author{
By \\ K. YAMADA, M.D. \\ From the E.N.T. Department, Nagoya University School of Medichine
}

(Director: Prof. S. Goto M.D.)

Hearing test above the threshold has been experimented in various ways for differential diagnosis for so-called perceptive deafness. However, all the methods experimented so far have certain advantages as well as disadvantages. Therefore, a new method was experimented in the test above the threshold of hearing on one ear, clarifying the significance and fundamentals of the test. Method of the test:

1. The hearing-loss curve was prepared.

2. A sound of $20 \mathrm{db}$. above the threshold was applied to a subject, the loudness being lkept in his mind.

3. A point was seeked where the sound of the same frequency reached the same loudness of the sound mentioned in 2 above by increasing the former from $0 \mathrm{db}$.

4. A point was seeked where the sound of the same frequency reached the same loudness of the sound mentioned in 2 above by decreasing the former from $90 \mathrm{db}$.

It was found, then, that some difference between the first point and the second point appeared for sounds of various freqnencies. The distance between these points was taken as the result, Although modulations were carried out not only at $20 \mathrm{db}$. above threshold but also at $40 \mathrm{db}$. and $60 \mathrm{db}$ above threshold, the results obtained at $20 \mathrm{db}$. above threshold will be mainly explained in the following.

Results of the test:

The difference between the two points (hereafter referred to as the range of sensibility) was about 8 to $15 \mathrm{db}$. for those whose hearing organ was ordinary as well as fot those of conduction deafness, while it was different for those of perceptive deafness. For instance, in Meniere's disease, the range was naraower. In central deafness, the range was wider. Most cases having positive recruitment phenomenon showed narrower range. These results indicated that the test had certain relations to the recruitment phenomenon.

Following that indication, the test was experimented on animals with lesions of Corti's organs by giving a sound of various intensity to them only to ascertain the occurrence of recruitment phenomenon. Furthermore, in parallel to the test that sound stimulation caused the shift in the threshold of those with normal hearing ability, it was found that the range of sensibility of those with normal hearing ability got narrower after immediately after sound stimulation as the tone of sound became higher. The fact seemed to indicate that the test could be applied to ascertain a lesion in Corti's organ and the existence of recruitment.

From the results mentioned above, it can be assumed that:

(1) Cases showing narrower ranges indicate a lesion in Corti's orgarn.

(2) Cases showing normal ranges have either a lesion in acoustic nerve, in variation of !abyrinthine fluid. or lesions both in the acoustic center and. Corti's orgarn.

(3) Cases showing wider ranges have lesions in the acoustic center.

(4) This test above threshold is cambe applied to one ear in order to diagnosis of possible localization of lesions in percetive deafness. 


\title{
閾值上における一聴力検查法
}

\author{
第 1 編 臨 床的研 究
}

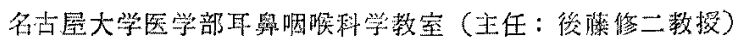

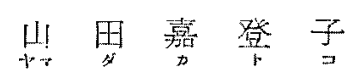

\section{内容目次}

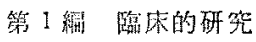

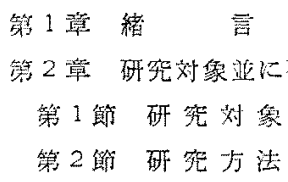

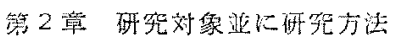

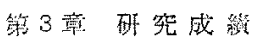

$$
\begin{aligned}
& \text { 第1節 正常耳儿就引成維 }
\end{aligned}
$$

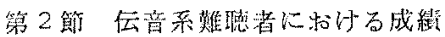

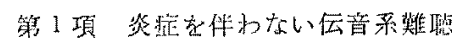

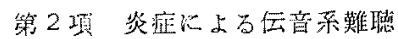

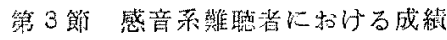

$$
\begin{aligned}
& \text { 第 } 1 \text { 項 } x=x 一 \text { 氏荡 }
\end{aligned}
$$

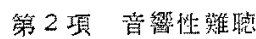

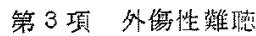

$$
\begin{aligned}
& \text { 第 } 4 \text { 項 老人性難俧 }
\end{aligned}
$$

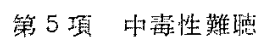

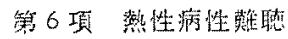

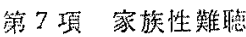

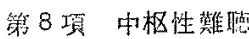

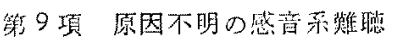

第 4 斯 铚括並以考校

(1) 渎 力 啠

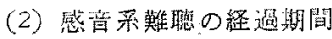

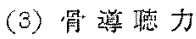

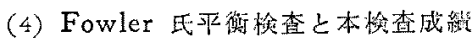

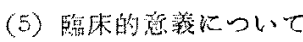

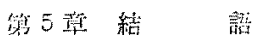

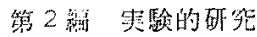

第1意綨乼

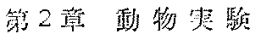

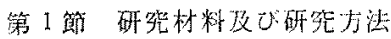

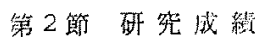

第1項猫の正常田に和ける成緥

第 2 项 病的匠の成維
第了幊 本節の小括

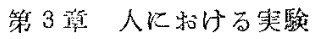

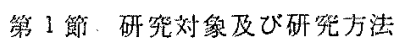

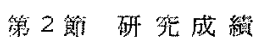

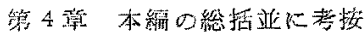

籍 5 章 結萿

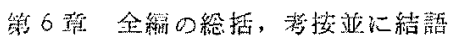

第 1 節 全編の䍃括，考按

第 2 節 䋩䓊

主要努擜

\section{第 1 虽 緒氞}

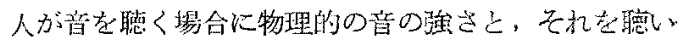
た時の感覚レベルの大きさは，凡ての人が同じょうに感 ずるのでしようか?

1924 年に Pohlman Kranz は念激な閶䛧の低下を認

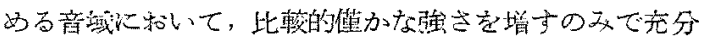

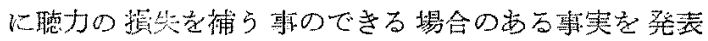
し, 棌いて 1928 年 E.P. Fowler ばオーデオメーター

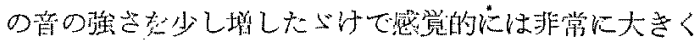

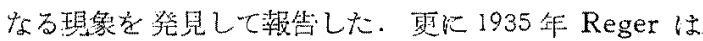

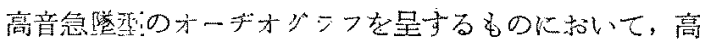

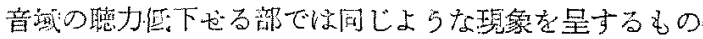
のある泰発表している。これらは凡て可聴閥值上にお ける物理的望の强さに刘する感觉レバルの大きについ て懈しているのであり，1936 年画び E.P. Fowlerは四 耳に预いてこの大きさの比较を行らことによつて，音の

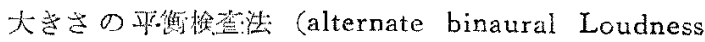

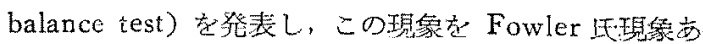
るいは Recruiment 瑟象と称すると共に，所譄感音柔 難㯖に特異的なものであつて，これによって伝音，感音

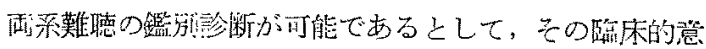
義を強賙したのである。

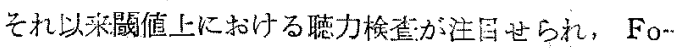

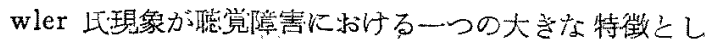
て暲に冓大視されるようになつたのである。1937年 
Steinberg u. Gardner 等によつて本現象は確認さら

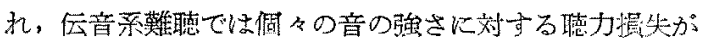
一定であることから Constant hearingloss type と呼

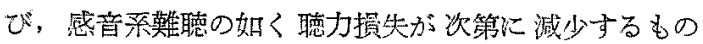
き Variable hearingloss type と呼んだ.一方 1941 年

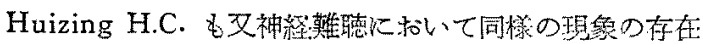
を別に Regression と航儿で発表した。

Fowler はその後舟1941 年, 1950 年以同埭の結果を

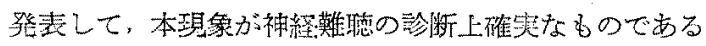

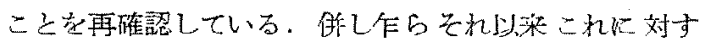

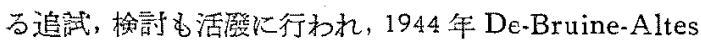

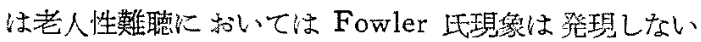

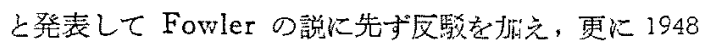
年に Dix, Hallpike, Hood 等は Labyrinthäre hydrops では Recruitment 現象を呈するが，第8脳神経の 障害では Recruitment 現象を認めないと発袁し, 本現

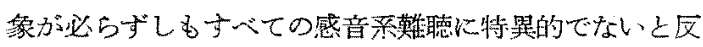
䮈している.この詵は Eby and Williams, Lüscher and Ermanie, Lundborg その伅によつてい䜀められ 当に至つたが, Dix, Hood 等は更に Recruitment 现

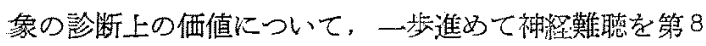

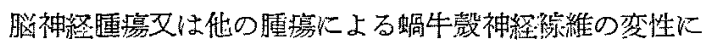

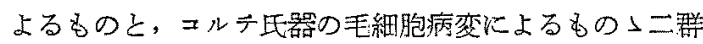
に分ち, 神経院誰病変では Recruitment 現象を認めな いことが特徴であり，コルテ氏器の毛細胞病変では本現 象陽性であるといら蹦床的知見からして, Recruitment

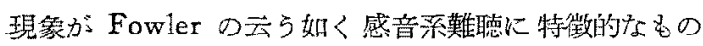
とは云えないか゚，神経難德を上述した二つの type K 鑑别するといら竞断上の価值を゙つものであるとして， Recruitment 琶铲の存在の意義衣强調している。

本邦に执いては，1949年名大後藤教授によつて咍め て注目己れ，更に1950年小出は中耳炎性難聴において

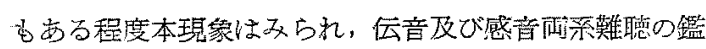
则上補助的手段に過ぎないと報告し，1952 年塩谷は本

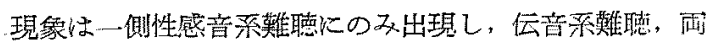
側性感音柔難龽には出琶しない之述べている。

1953 年 Bangs and Mullins が批判した如く望の大 きさ平衡检息恃最も確実性のるる Recruitment 测定法 ではあるが，唯一のそして最大の久点としてその適月は 一側性の疾患に限られる。即方 Fowler 氏法の施行に は元来対象となる正常耳を要するのみであつて，この点 臨床上の応用に際してはまさに致命的と云わ和ばならな い、何となれば私共が接する多くの聴䙼障䨐者ことに

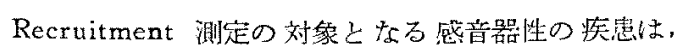

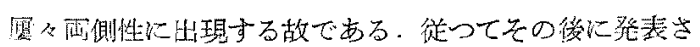
れた多くの Recruitment 测定法は先ず第1にこの欠点 を補足せん方゙たるであつた。

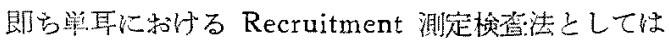
1936 年 Reger 4 monaural bifrequency Loudness balance test 発表した。この方法は比较する2音,

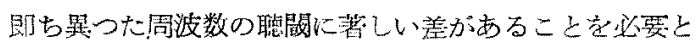
ᄂ, 且つ2つの周波数の差が大きいとその它の大ききの

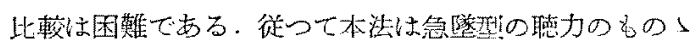
メに健朋し得るに渭ぎないのである。

1947 年 Békésyは閧健に就いて，Recruitmentを測 定しょらとして，所謂 Békésy 制オーヂオメーターを

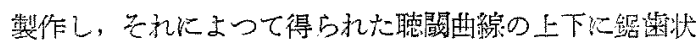

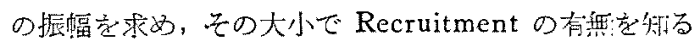
其ができると発表したが，1954 年 Hirsch, Palva and Goodmann はこれに站して Intensity Difference $\mathrm{Li}_{\mathrm{i}}$

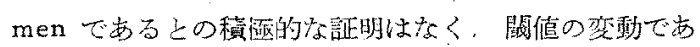
ると琎へている。

1948 年 Lüscher and Zwisloki は閣䛧上一定强度に おける音の振幅の変化を䁌䁖に感ずる最小值により弁別 閶を求めた。

1950 年 Dens and Naunton によつて始められた間 值上の或る2点に我ける Difference Limen の㩍の相

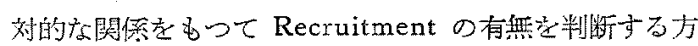
法が発表され，我が国に和いてもとの追試が行われると 共に，他为 Jerger は Difference Limen 值の減少の

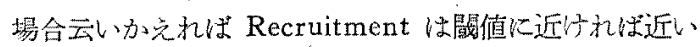

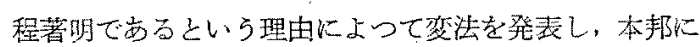

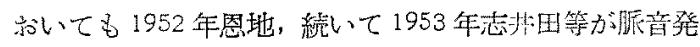

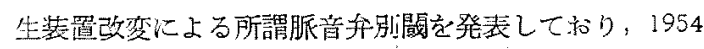
年河辺は音の强さと大きさとの関傒に就いて咞宛し，

Recruitment 晲象発現の本態はコルジ瓦器及び中耳等 障栉であると思考すると述べている。

かくて当時 Fowler's Recruitment Test の独䀨㛫の

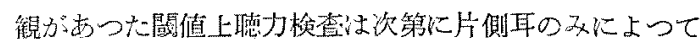
Recruitment 現象を証する事ができると共に，感音系

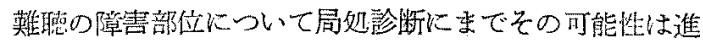
妨るに至つた。

私む页翟値上の音の強さと大きさとの関係について， 手別能によらないで Fowler 氏法之同様に同じ大きさ

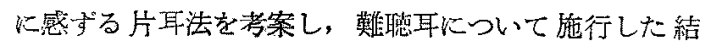
果，本検查法の臨床的澺義について些か知見を得たので 
報告する、なお本法の摡要は1952 年名大後藤教授によ つて, 耳與咽喉科 24 巻 11 号 13 頁及び 1954 年 9 月， The A.M.A. Archives ef Otolaryngology Vol. 60, pp. 342〜349に揭戴された。

\section{第 2 章 研究対象並に研究方法}

第 1 穊 研究対象

本研究の材制としては，炤和26年9月より炤和 27 年

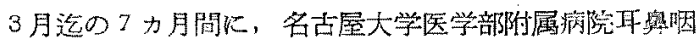

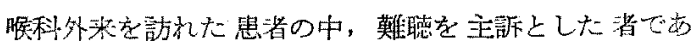
る.

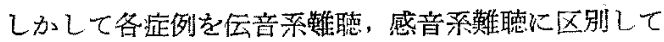
こ机空研究の乾象とした。

第2節 研究方法

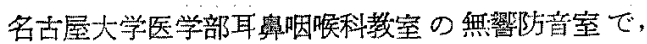

AMIS オーデオメーターを用いた。

先ずオージオグフフを作製し，次に最低可德閶值から $20 \mathrm{db}$ 上の音を聴取させて，この音の強さに拈ける大き さを筧党させて和く、次に Odbから順次音を強くして， 前の大きさと同し大きさに感じた点を第1に求め, 再び 䦨值上 $20 \mathrm{db}$ の音定㩊取させて，次に $90 \mathrm{db}$ から順次 音を弱くして基集音と同じ大きさに感じた点を第 2 に求 わる。しかる時は一つの音について，最低可聴間值上 をはさんで第 1 と第2の点との間にある幅が生ずる。こ

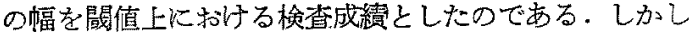
てこの梌整法を各振動数について行らと夫々の䒇が定め られる。

又最低可聴閶值上 $20 \mathrm{db}$ の他に，40db，60db におい ても同榢に施行したのであるが，難聴の程度によつては 䦪值上 $40 \mathrm{db} て ゙ の$ 検查不能の事も少くないので，40db 及び $60 \mathrm{db}$ 上のものは参考程度に留るものが多からた。

しかしてこの輻学覚幅と命名する事にする。

\section{第 3 章 研 究成繥}

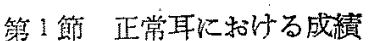

正常耳10耳についての成綕は第1 表に示寸如くであ る、これを一括表示したものは第2表の姐くであり，こ れを図示す木几第1画の如くである。

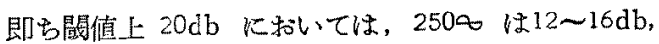
平均 $14 \mathrm{db}$ であり，500ם は $12 \sim 16 \mathrm{db}$, 平均 $14.6 \mathrm{db}$ であり，1000のは 13〜16db，平均 $14.5 \mathrm{db}$ であり，

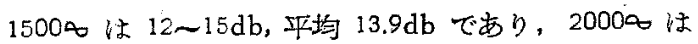
$10 \sim 15 \mathrm{db}$, 取均 $12.5 \mathrm{db}$ であり, 3009a は $11 \sim 15 \mathrm{db}$,

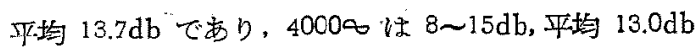
です、, 6000๙は9 9 16db, 平均 12.7db であり, 8000

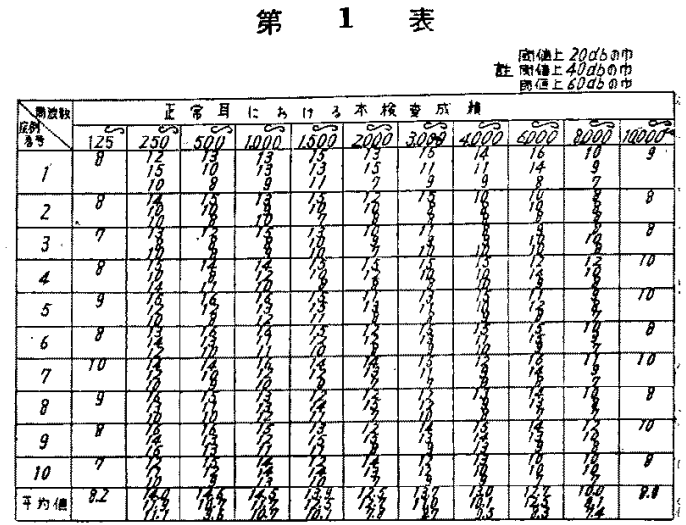

第 2 表 正常耳儿招行る本㮝查成維

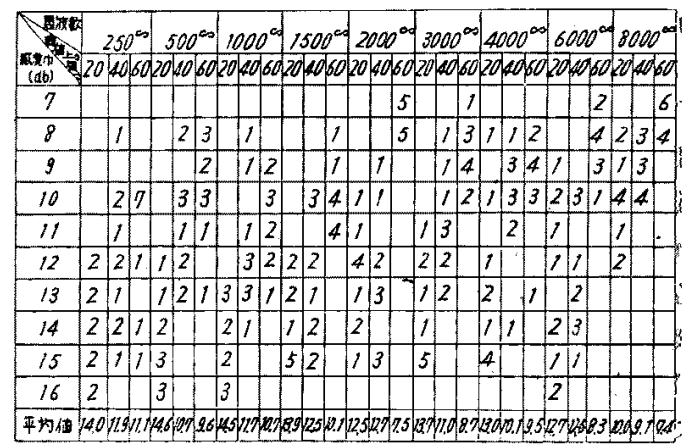

第 1 图正常耳.に和ける感賞幅 应例 正常耳平的値

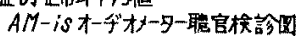

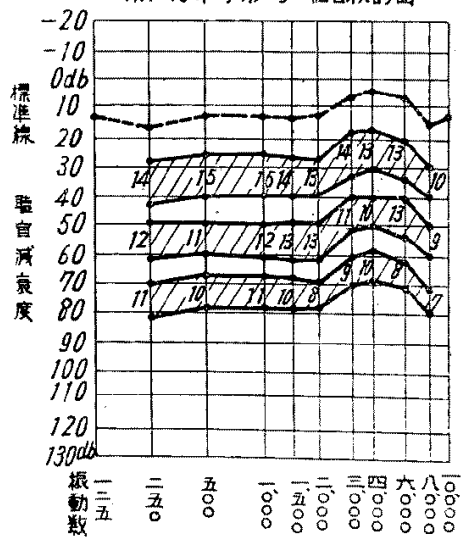

のは 8〜12db, 平均 $10.0 \mathrm{db}$ である.

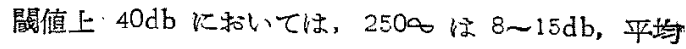
$11.9 \mathrm{db}$ であり, 500क は 8〜13db, 咕均 $10.7 \mathrm{db}$ であ り, 1000\& \& 8 14db, 平均 $11.7 \mathrm{db}$ であり, 1500ه は $10 \sim 15 \mathrm{db}$, 平均 $12.5 \mathrm{db}$ ですり, 20000 は 15db. 
顶均 $12.7 \mathrm{db}$ であり, 3000 \& は $8 \sim 13 \mathrm{db}$, 平均 $11.0 \mathrm{db}$ であり，4000のは 8〜14db, 平鸤 $10.1 \mathrm{db}$ であり，6000 のは10〜15db, 平均 $12.5 \mathrm{db}$ であり, 8000めは8〜11 $\mathrm{db}$, 平均 $9.1 \mathrm{db}$ である。

閾値上 60db におい、ては，250ðは 10〜15db，平均 $11.1 \mathrm{db}$ であり, 500क は 8 13db, 可均 $9.6 \mathrm{db}$ であり,

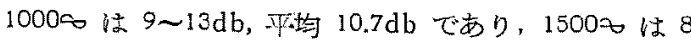

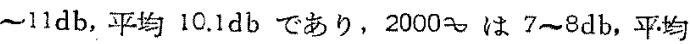
$7.5 \mathrm{db}$ であり, $3000 \gtrsim は 7 〜 10 \mathrm{db}$, 平均 $8.7 \mathrm{db} て ゙ あ り ，$ $4000 \diamond$ は 8 13db, 平均 $9.5 \mathrm{db}$ であり, 6000 江 7 $\sim 10 \mathrm{db}$, 平均 8,3db であり, 8000 代7 8db, 平绚 $7.4 \mathrm{db}$ である。

周波数を考慮せずに緾めると，閾佂上 $20 \mathrm{db}$ の強さに おいては 8〜15db の幅であり, 閥値上 $40 \mathrm{db}$ の強さに

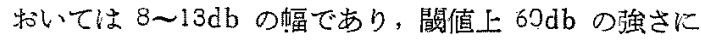
机いては 7〜11db の䒇である。

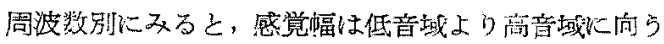
に従いその幅はや」縮小の傾问がないでもないが大差は 認好市なな。

これ等の成結加ら本检香法の正常值は周没数に大きな 関俰のない事を知つた。

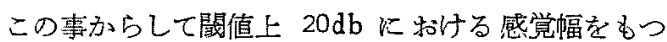
て，本挣套法の成續を渗定しても愦りないるのと思考与 万.

\section{第2 節 伝音忽難㴔者に招ける战續}

第1項 炎症を伴わない云音柔難㮦

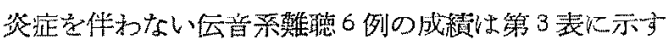
如くで势る。症例 5 及び6は备周波数已も正常時の感賞 幅を，症例 I，2．3，4 は周波数に上つては感觉幅は正常 值万至少し大である(第2図)，各音域に抋いての差異 は認められず，感覚湢は注ら゙正管值である。

第 3 表 炎症を伴わない伝管采難聴

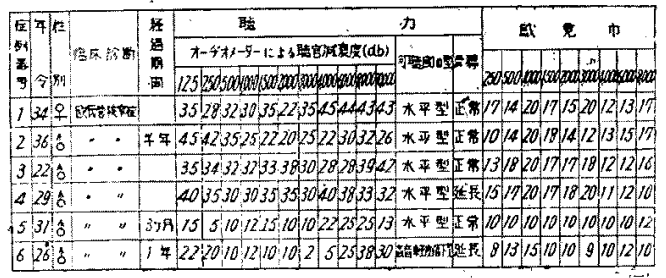

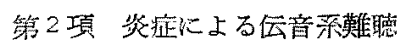

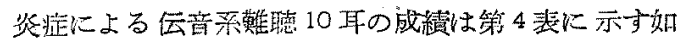
くでする.慢性中耳化澧湍6 例のうち, 症例 7 は正常の

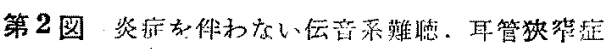

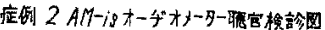

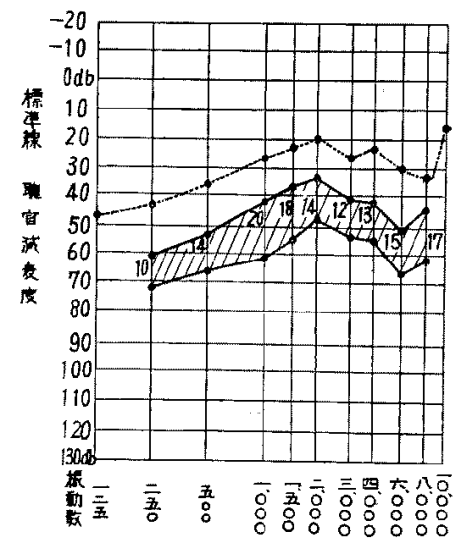

第 4 表 炎症による质音矆㬝

\begin{tabular}{|c|c|c|c|c|}
\hline \multirow{3}{*}{ 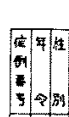 } & & & \multicolumn{2}{|c|}{ 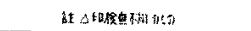 } \\
\hline & & : 㥰 & s & $\pi$ \\
\hline & & 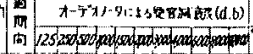 & & 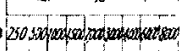 \\
\hline $7 / 189$ & 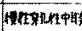 & 451500515566465606052525445 & 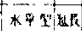 & 1119.1010101015148 \\
\hline 8347 & . & 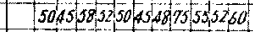 & & $15,213: 202200079$ \\
\hline $9 \ln 7$ & $"$ & 555040545400422425446060 & : & 1616121881214181915 \\
\hline $10 \operatorname{lng}$ & 中期期 & 454042250424022402535155 & IF & $171622202017,1517,66$ \\
\hline 11223 & 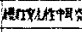 & 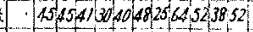 & & 20222200182314191723 \\
\hline 12207 & 8桂中日获 & 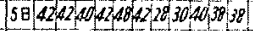 & & $1 3 \longdiv { 1 5 / 2 1 3 1 0 1 0 1 0 , 5 1 0 0 }$ \\
\hline 13209 & 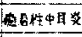 & $4 / 2235405231825550651$ & L n & 81010161610898 \\
\hline $1423 \sqrt{5}$ & 然土的中目员 & 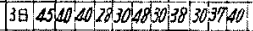 & *平里 & 815201312152 \\
\hline $1519 \div$ & 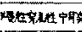 & 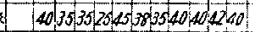 & & $2018012757: 78,7172010$ \\
\hline $16 \mathrm{p}$ & 慜被中耳落 & 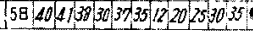 & HAEDE & 223523524 \\
\hline
\end{tabular}

第 3 図 慢性穿孔性化䑏性中耳炎

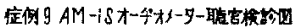

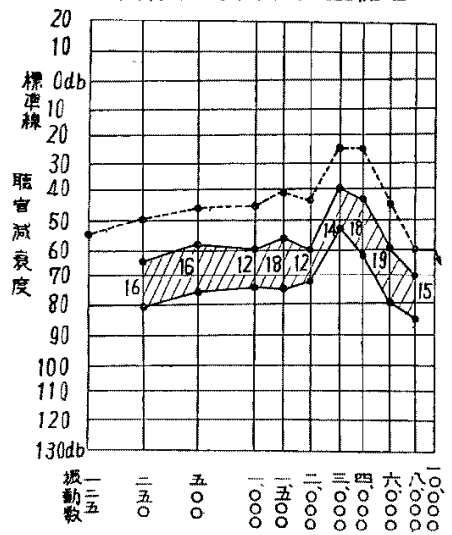

感覚愊を，症例 8，9，10，11，1505耳周波数に上つ て感賞幅は正常倠乃至少し大である(第3，4図）。急性 中耳炎の症例 12 怔党の感覚幅を，痛着性中耳炎の症 例 13 子同様である。 
第 4 图 摱性穿孔性化脿性中耳炎

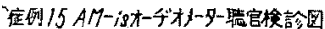

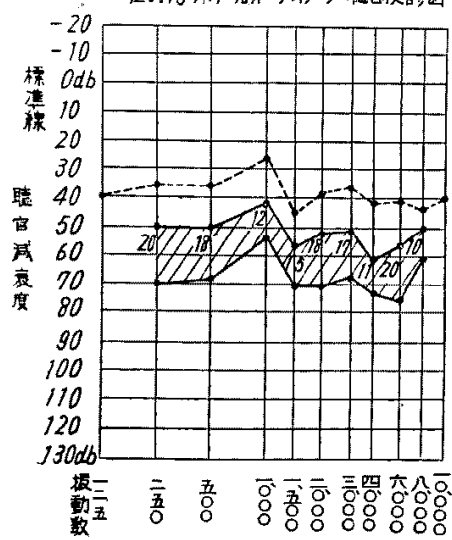

第 5 図 滲出性中耳炎

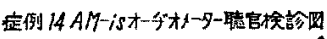

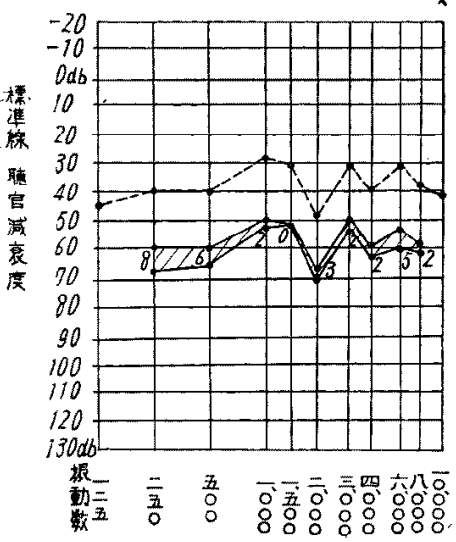

滲出性中耳资の 症例 14,16は正営の感覚幅より小で 古吕(第5四)

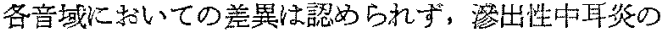
2 例を除いて他ははよ゙正常值である。

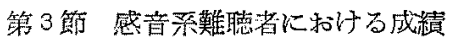

感堭柔難㯖はこれを原因別に分けて観祭した。

第 1 項 $x= \pm$ - 氐病

xニエール氏㾈13耳について测定した放綪は第5 表 に記した如くである。

$x=エ ー ル 氏$ 病の检登に当つては，発作時ではなく て，間欠時の比較的笠定した時期のものである。

周波数によつては感覚幅が小であるものは症例 192 , $3,4,6,7,8,9,10,12,13 \sigma 11$ 耳であり(第6図), 各 周波数共感覚偪小のものは症例 5，11 である(第7 図)，
第 5 表 メ エ エル氏病
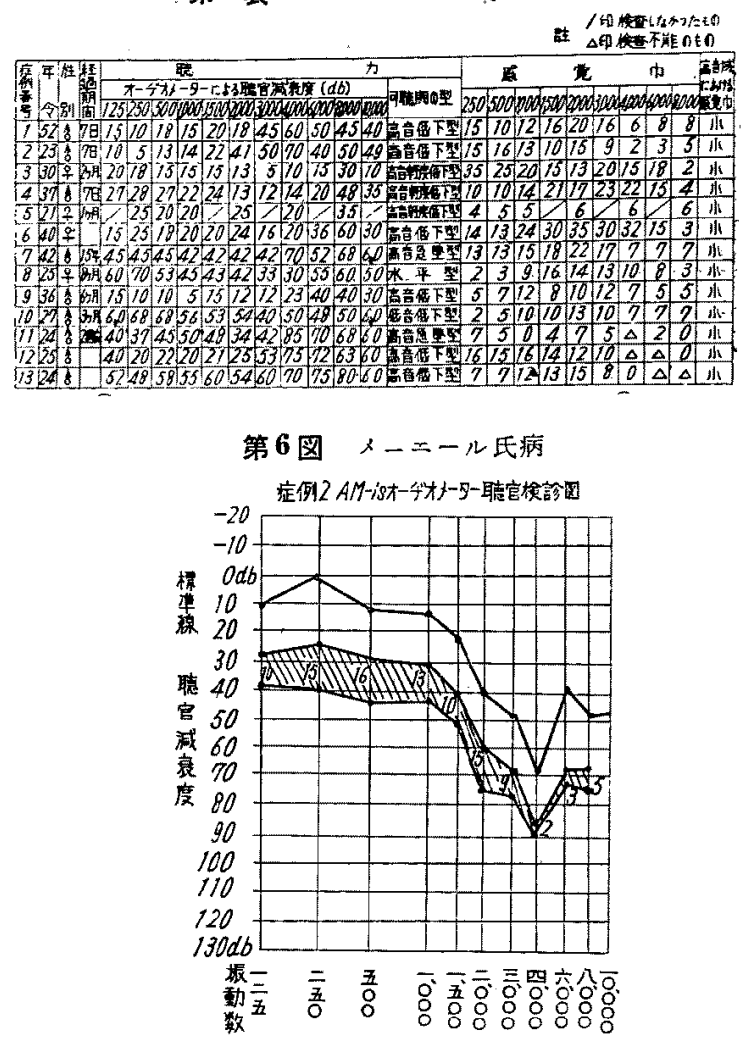

第7図 $x=$ 一兀氏病

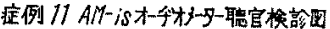

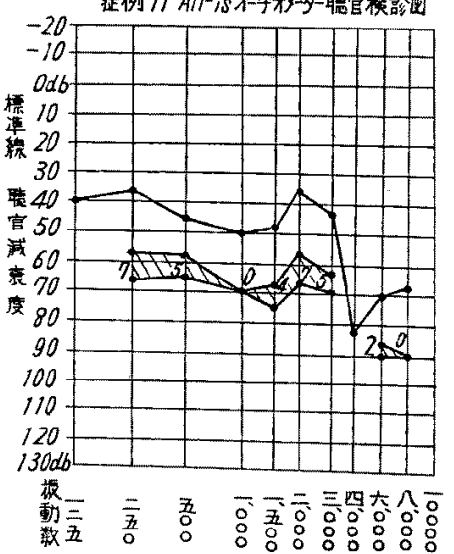

各周波数共正常時の鐁国にあるもの（以後感党楅中と 棌する）及び大であるものは認められない

衈力の低下した高音域で，症例 2，3，4，5，6，7，9,10 の 8 耳は 4000,6000,8000 の各周波数共感覚幅は小であ 


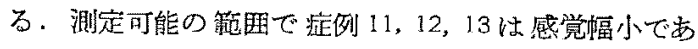
り，各周波数の感営幅の発現状態より测定不能の周波数

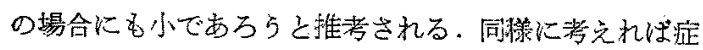
例 1 及び8は最も但下した高音は感覚幅小であり，他の 高音は中言域比してその腷は狭くなり，且最低正常值

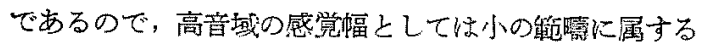
ものと解釈する。

かくの如く観察した結黑は、メニメール氏病の全例が 高音域の感覚幅小を呈した。

\section{第 2 項 音響性難聴}

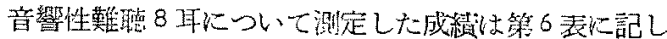
た如くである。

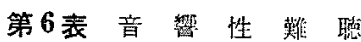

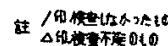

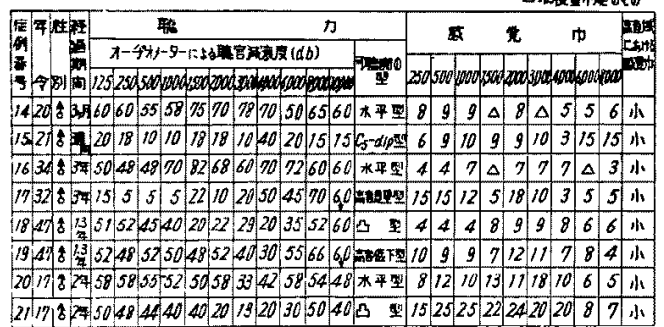

周波数によつては感覚幅は中文は少し大のものもある

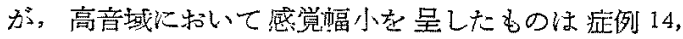
$15,17,18 ， 19 ， 20 ， 21$ で屴り，全国周波数共感党幅小で あるものは症例 16 である。全周波数に执いて，感敩幅 中页は大であるものは認められない。

聴力の低下した高音域 (4000 8000そ) で症例 14, $15 ， 17 １ 8 ， 19$ は凡て感覚幅小である（第8図）。

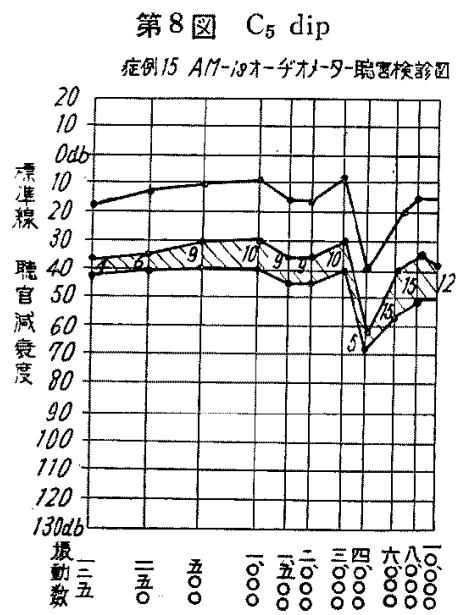

症例 16 は 6000 岋湘定不能であるが 4000 及び 8000 ○は感覚幅小であり，この周波数も小之推考される。症 例 20,21 は周波数に上つては感党幅は中であるが, 症 例20は4000もで中音琙よりぐつ之幅は狭くなり 6000 及び 8000○で小であり，高音域の感覚幅は小の範疇に スるものと推考される. 症例 21 は 6000 で聴力低下 しその感誉幅は最低正常値であり，8000ので小である

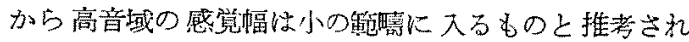
る.かくの如く钼案した結来は，全例が高音域で感覚幅 は小である。

\section{第3 項 外傷性難缌}

外傷性蜼聴 6 耳について测定した成續は第 7 表に記し は如くでかる。

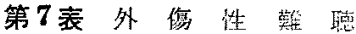

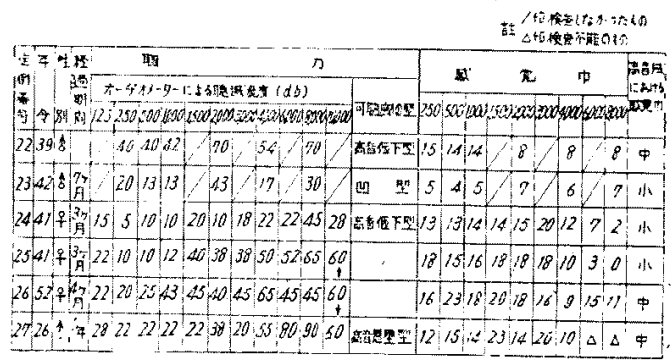

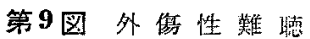

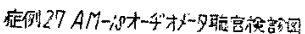

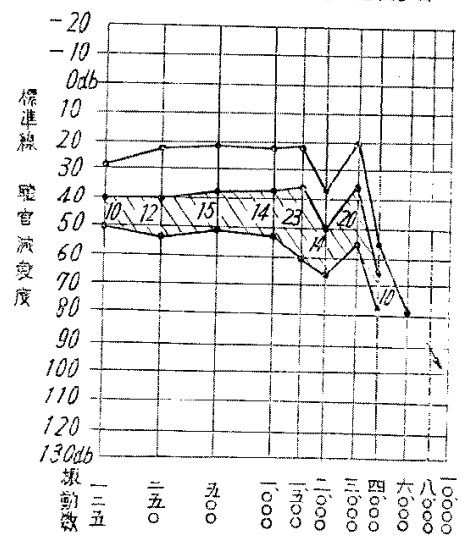

周波数によっては感觉幅は少し大のもの，中のもの， 小のむのが混在する症例 24 及び 25 があり，全周波数共 中である症例 22，周波数によつては中文は少し大である 症例 26，27がある（第9図）、全周波数が大の60は認 められない，測定した全周波数が小は症例 23 である。 聴力の低下した高音域で症例 24, 25 は 40000 が感 


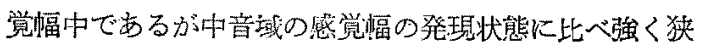
くなつて扰り，6000 及び 8000めで小となるため，高 音域の感覚幅は小と推考さ机る. 症例 22,26は感覚湢 中であり, 症例 27 は 60007 以上は测定不能であるが 4000の は中であるから，6000ぇ以上はあるいは小とな る場合も考兄られない事出ないが，一応感觉幅は中と推 考する。

以上の結果から本項目においては，高音域の感覚愊は 小のもの及び中のものが各半数を占めている.

第 4 項 㳣人性蜼聴

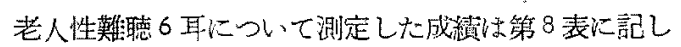
た如くである。

第 8 表 老人性 難 聴

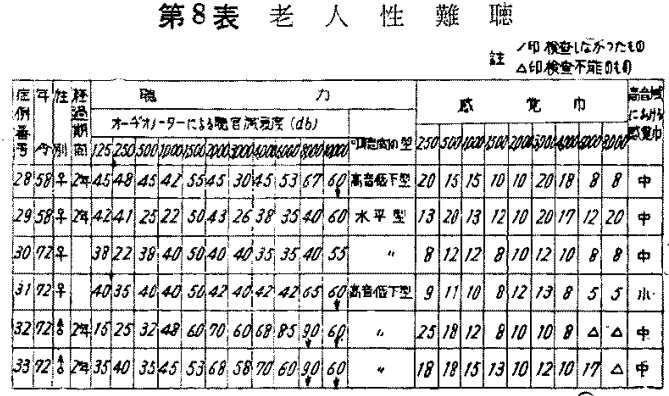

第 10 图老人性難淘

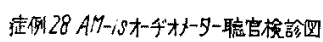

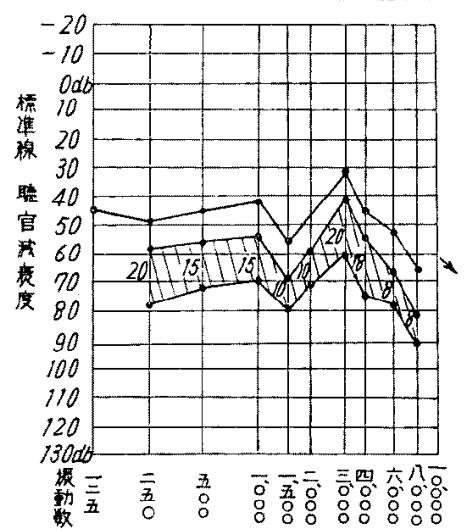

周波数によつては感賞幅は中历湢少し大のものもある が，高音域が小となつた例もある。

聴力の低下した高音域で，症列 31 は 40008 の感覚 愊は中であるが，正常值の最小であり，同聴力の中音域 の幅は中でも広い方によつており，6000及び 8000乞は 小であるので，商音琪の感党幅は小と推考される，症例 28，29は高音域の周波数によつては感覚幅は少し大のも
のもあるが全体として中である（第10図），症例30 は

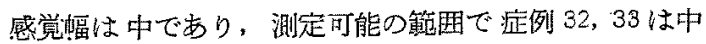
音域より聴力低下の周波数が感敩幅中であるので高音琙 は中々推考する。

即ち本項目においては感觉幅の発現は，高音域で小の もの及び中のもの>两者があるが，6例中 5 例が感覚湢 中老占めている。

\section{第 5 項 中言性醀聴}

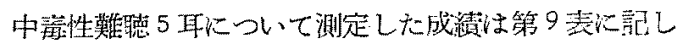
た如くである。

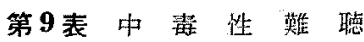

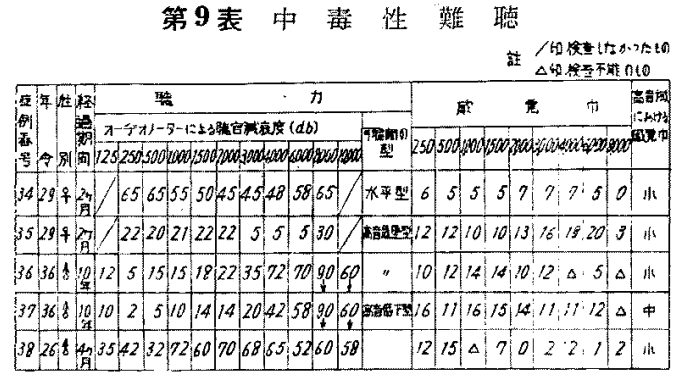

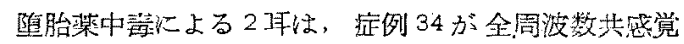
輻小であり（第11图），症例 35 は䁨力低下の高音域で 感賞揊小となる。

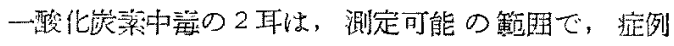

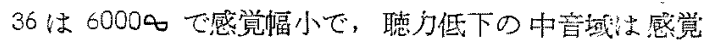

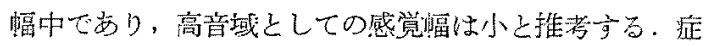

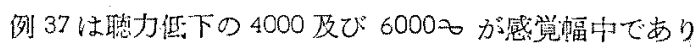

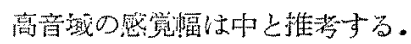

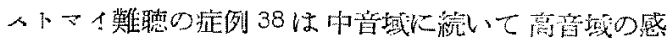

第 11 图中毒性難鲶

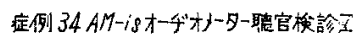

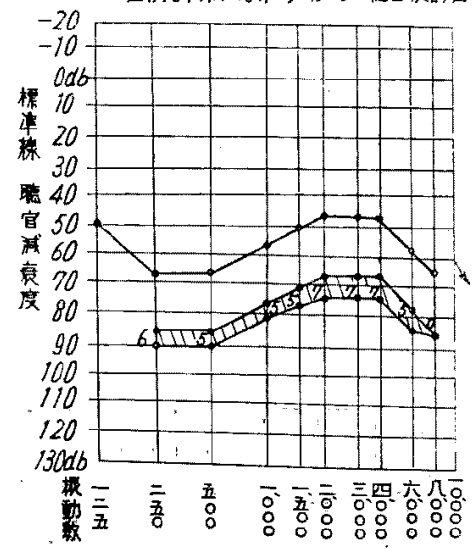


覚幅は小である。

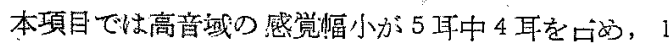

耳が中である。

\section{第6 項 䓡性病性難衈}

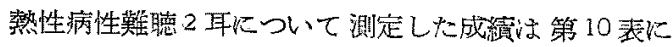
記した如くである。

症例 39，40 共聴力细下した高音域の 鼠覚輻は小であ る(第 12 区

第 10 熱性病性難衈

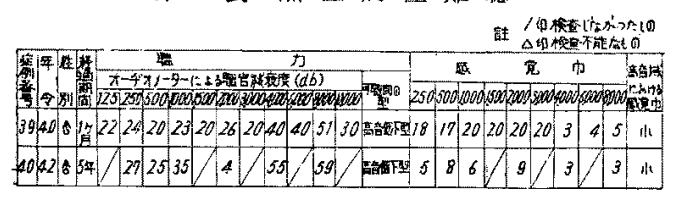

第 12 図 䏶性病後性䊮衈

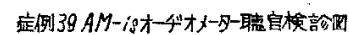

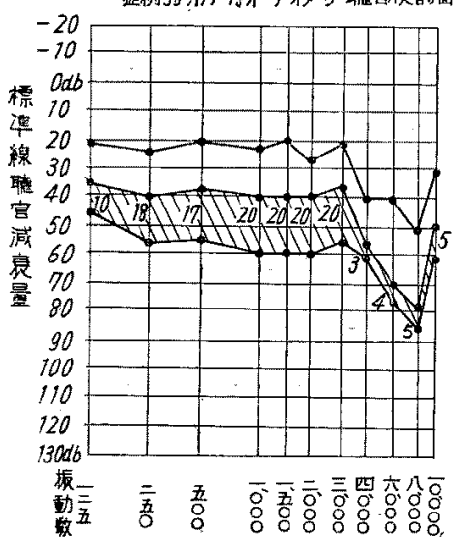

第 7 工 頁 家政性蜼婹

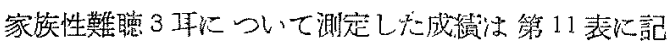
乙た如くである。

症例 41,43 は全周波数共感覚湢は正常感覚㽬上り大 であり，殊に $6000 \approx の$ 聴力が策かに低下をした場合も

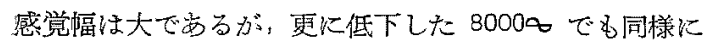
大である(第13図)，症例 42 は周波数炕よつては少し 大である所もあるが，高頭域测感覚幅中である，感覚幅 小のものは認められない。

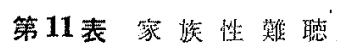

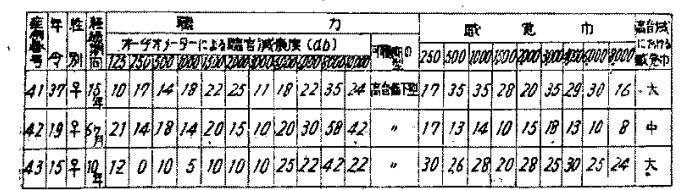

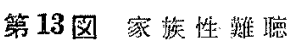

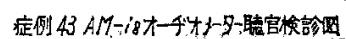

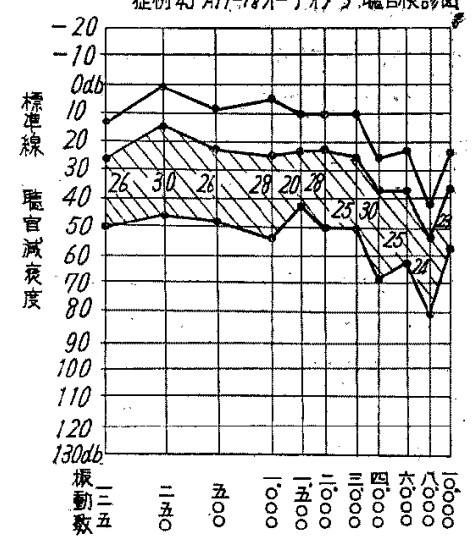

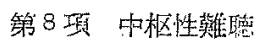

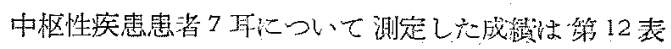
に記した如くである。

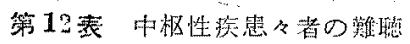

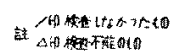

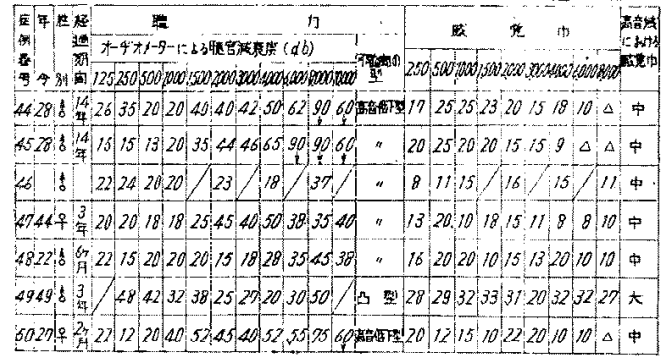

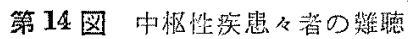
(ハッジンッン氏病)

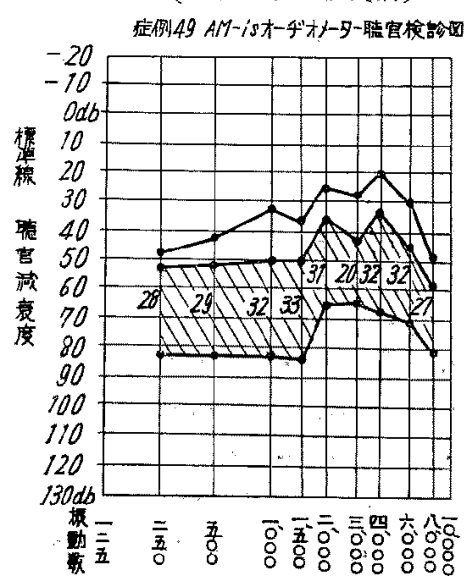


症例 44，45は小脳疾患葸者で測定可能の籍围では周 波数によつては感䋟湢虫乃至大である，症例 46，47， 48，50は瀕㴼で，症例 46 は全周波数の感覚幅は中であ

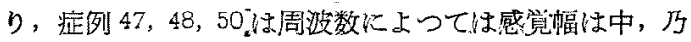
至大である。

症例 49 (ハッデンッン氏㾋) は凡ての周波数に捣いて 感觉愊は大でるる(第14 図)。

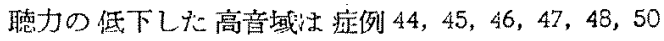
の6 耳は感覚輻中であり，症例 49 は大である。本項目 では聴力低下の高音域に执いても感覚標小のものは認め られない.

第9項 原因不明の感去采難衈

以上の原因別にみた感音系摹㯖についての本检查成續 から感覚輻は大，中，小の三者に分つ勡ができた，原因

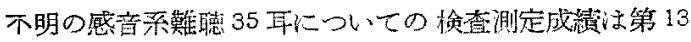
余に示した妈くである。

症例 65,79,83, 及び测定可能の筷国で症例 59,60,73 は感登幅は怒图波数が中である(第15图)。

症例 $51,52,53,69,72,74$ 及び测定可能の籍围で症 例 $55 ， 66 ， 70 ， 71 ， 85$ は周波数によつて感覚幅中乃至小 である・

第 13 表（1）原因不明

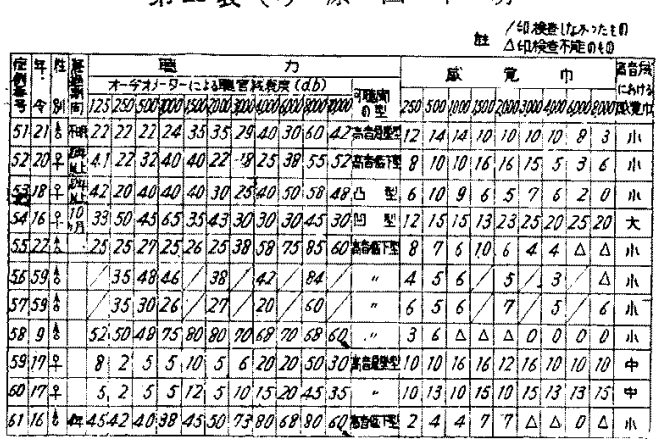

第 13 佘（2）原 因不明

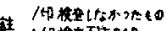

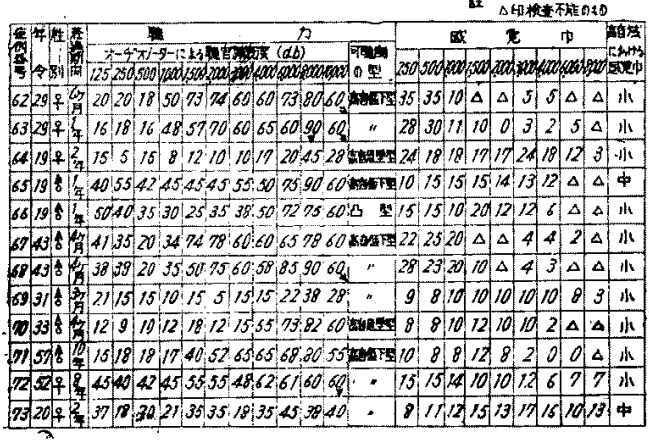

第13表（3）原 因 不・明

149,

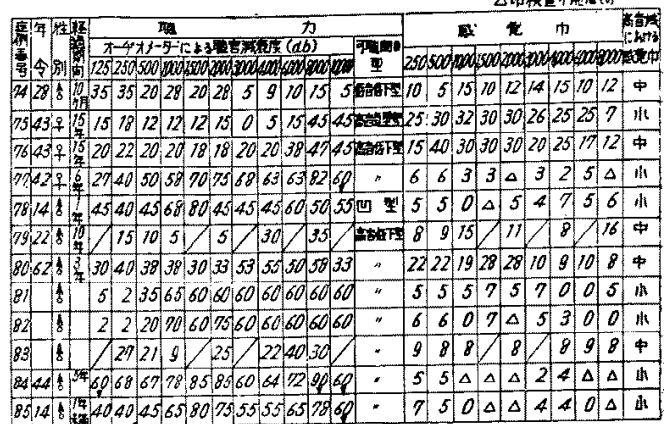

第15图 原因不鹏の感音秀難㳳

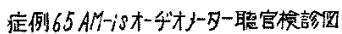

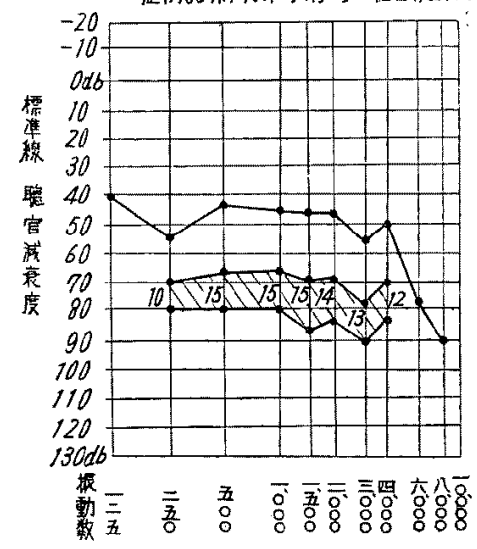

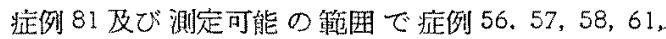
$77,73,82,84,85$ は各周波数の感覚幅は小である。

症例 54，76，80は周波数によつては感賞腷中乃至大で ある・

症例 75 及び測定可能の簿国で症例 67 《周㝿数によつ ては感覚楅は太及び小である。

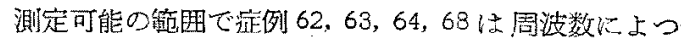
ては感筧幅は大，中，㕛は小である。

喯力の低下゙した高音域において，症例 $51 ， 52,53,55$, $56,57,58,61,62,63,64,66,67,68,69,70,71,72$, $75,77,78,81,82,84,85025$ 耳沙営幅小である。

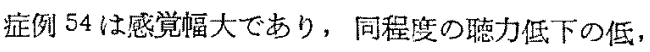

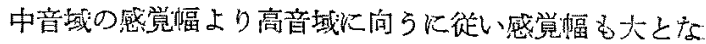
万.

庭例 59, 60, 65, 73, 74, 76,79,80,83の9耳は感賞 幅ばやである(第16图)。 
第 16 図原因不明の婜音杀難德

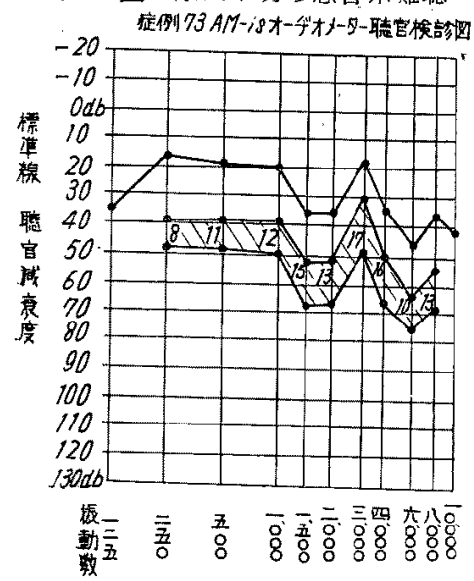

第 4 章 紷括並に考按

以上の成程を総括し，これ等の成續のよつてくる原因 について分析し，考察老扣えてみる。

伝音厓鹳㯖では淩出性中耳炎以外のるのは，感覚幅は 中㕛は少し大である。

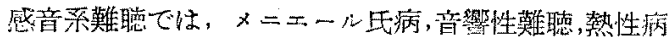

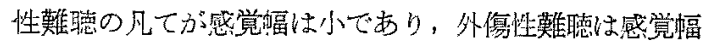
小と中が半々を占め, 老人性難㯖は 6 耳中 5 耳が感筧幅

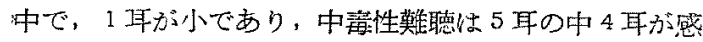
覚幅小た，1耳が中であり，家㵀性難恋 3 耳の中 2 耳が 感覚幅大，1 耳が中であり，中枢性疾患患渚7耳の中， 感営幅大が 1 耳, 中が6耳である。

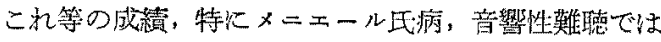
感蛍幅がいずれる小であり，中枢性疾患のものでは感覚 楅が大である事からして，感筧幅の大，小の結果は病变

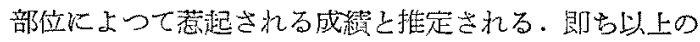
臨床成續からして感覚偪の小で亦るるのはコルデ氏器に 主病变あるものであり，大であるものは中枢に病変のあ るるのと推湘される。

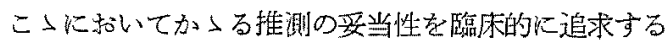

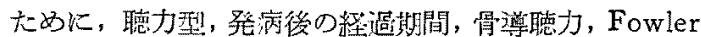

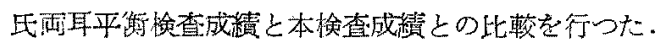

(1) 面 力 型

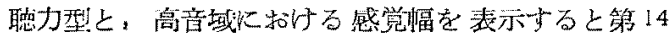
表の如くである（但し，高音急壁型性别武に記す）。

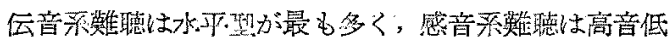
下型及び急型が多い。

水平型の伝音系難㯖では，感筧偪は中が多く(69\%), 小極めて少く $(6 \%)$, 大はない。
第 14 表 聴力型と感営幅との関保

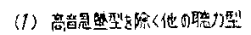

\begin{tabular}{|c|c|c|c|}
\hline \multirow{2}{*}{ 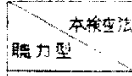 } & \multicolumn{3}{|c|}{ 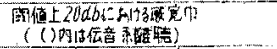 } \\
\hline & $\star 太$ & 4 & -3 \\
\hline 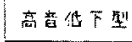 & 2 & $19^{\circ}(2)^{\prime}$ & 34 \\
\hline 水 严 㤠 & & $2(11)$ & 54 \\
\hline 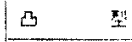 & 1 & (1) & 4 \\
\hline 凹 & 1 & & 2 \\
\hline 传番佂下型 & & 1 & $p(1)$ \\
\hline
\end{tabular}

(2) 高盖急慗

\begin{tabular}{|c|c|c|c|}
\hline \multirow{2}{*}{$\begin{array}{c}\text { 本楥龺法 } \\
\text { 譃力型 }\end{array}$} & \multicolumn{3}{|c|}{ 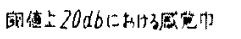 } \\
\hline & 大 & $\phi$ & In \\
\hline 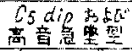 & & 3 & 10 \\
\hline
\end{tabular}

(3)

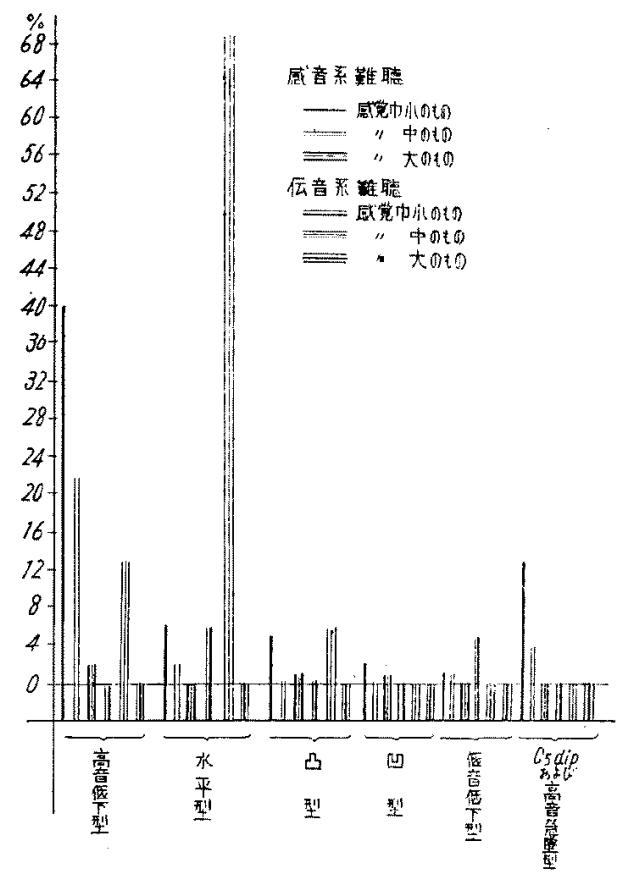

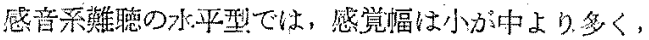

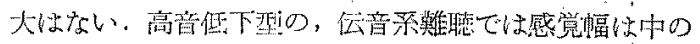
みでする。

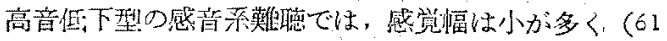
\%), 次いで中 $(35 \%)$, 大は崡めて少い。

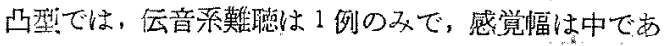
り，感音系難悖では感覚湢は中はなく，大が1例の及 で小は4例である。 
凹型では，质音系難聴はなく，感音系難聴は感覚幅は 小が2例, 大は1例である。

低音低下型では，伝音系難聴は感覚幅が小のもの1例 のみで，その他はなく，感音系難聴では感覚愊は小及び 中が夫ネ 1 例である。

$\mathrm{C}_{5} \mathrm{dip}$ は感喾幅が小であり，写の他の急墜型の感覚幅 は小が多く，僬加に中が認められた。

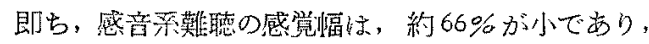
約 29\%か゚中であり，残りの5\%が大である。

他方，伝音柔難聴は殆んどが水平型で占めら㣗ている

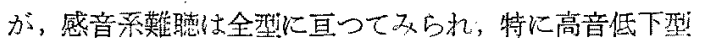
改び急丞型が特異的に多い。

(2) 感音柔鹳聴の経過期間

感音系嚾聴の経過期間と感覚幅との関保を圭示すれ ば，第15表の如くである。

各原因別にこれを钼察すると，メニエール氏病は自覚 してからの経過期間が 1.5 年迄で短く, 全例が感覚幅は 小である。

第 15 表 感咅系雉婹の経過期間々の関係

\begin{tabular}{|c|c|c|c|}
\hline 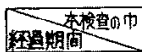 & 太 & $\phi$ & 4: \\
\hline クク月まで & & & 7 \\
\hline ろร月まて & & 1 & 8 \\
\hline 65 月ะ & & 3 & 6 \\
\hline ノ々年士 ‡゙ & 7 & 3 & 6 \\
\hline ろク年まで & 2 & 8 & 9 \\
\hline 5ク年まで & & 2 & 3 \\
\hline 10ヶ年まて & 1 & 2 & 4 \\
\hline 107 年 & & 2 & 2 \\
\hline
\end{tabular}

音響性難㯖む3年迄で，全例が感覚幅は小でるる。

外傷性難㯖は 1 年迄で経過期間は短いが，感党幅は小 又は中が各半数を占めている.

老人性難聴は無自覚例に感覚幅が小であり，自覚後の 経過期間 2 年のものでは，感覚幅は中である。

中壳性難聴の経過期間の短いものは凡て感覚幅は小で あり，10年を経たものでも，感喾幅は小あるい法中で ある。

家族性難㯖 3 例の中, 難聴自覚後 6 力月のむのは高音 域の感賞幅は中であり，10 年以上絰過したものは大で ある、感覚幅の小のものは認められない。

中枢性疾患の難㯖は感賞幅が中のものは経過期間の長 短に無関係であり，大のものは1例のみで，この関保は 不明である。
以上の成績を纏可てみると，感覚湢の小のものは発病 後の経遄期間の短いものが，長いものに比較して少し多

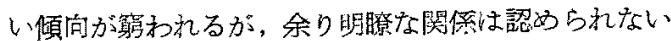

感賞幅中のもの法経過期間の短いもの上りは，長いも の今方に比较的多くなる傾向が筫われ，感賞幅の大のも のはカ6月以内には見られない。

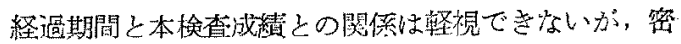
彩仪関連があると恃云い切れない。

(3) 涓尊聴力

骨導閥值の短縮あるいは延長は夫夫感音系障青並に伝 音系障害の晾断上重要な価值を有するものとして, 殊に 感音系障害の彭断上その占める意義は大である。

そこで骨導聴力と本検查成演との関係はどうであうう か，一括老示す礼ぱ第16 表の如くである，骨導閥值短 繀のもの>中, 過半数が感觉幅は小である. 感営幅が中 で骨導闌值が正常及び延長は伝音系難㯖の場合である。

第 16 表 骨尊との関係（伝音感音两烈 含を)

\begin{tabular}{|c|c|c|c|}
\hline 负 & 大 & 中 & 木 \\
\hline 正常 & & $g$ & $\times 6$ \\
\hline 短 & 4 & 22 & 53 \\
\hline 延 長 & & 7 & \\
\hline
\end{tabular}

骨導閾值正常て感覚幅小のものは滲出性中耳炎の場合 及び感音䂆難聴の症例 17，18，19，75でいずれむ中耳炎 に䍜患した事しなく，既往症は症例17はマシリヤ，症 例 18，19，75 は脚気に夫々羅患したの及である。

浸出性中耳炎の場合, 感喾幅小である事は, 可逆的内

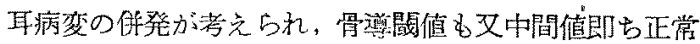
であるのは肯ける。

しかし，感音柔難聴の 4 耳は短縮を認め奴云うこと は，本検查法と骨導閧値との関傒は密接であるとは云克 ない。

术（1959年）は Recruitment test と云う点では

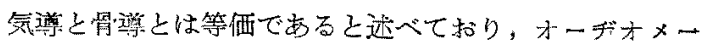
ターに上る今後の骨章聴力の检討が必要であると思う。

（4）Fowler 氏平衡検查之本检查成㺓

Fowler 氏平衡検直法亚に本検査法は共に物理的な音 の強さと感覚的レベルの大きさとの関係において，共に Recruitment 現象の有無老追求している.

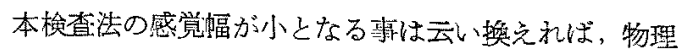
的音の強さに対する感覚的レべルの大きさが敏感のため と考兄られる。 


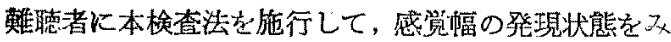
ると，大，中，小の三者に区別せられる。

高音急型型及び高音但下型に和いて，感賞幅が小であ るものが多い事は，音の大きさが上り急激借加すると いら因子と，昌の大きさの感じが大である时恃，本検笪 洗の感覚幅が小となるといら因子の二つが存在している のである。

本桧查法施行例の中，無撰択に17 再について Fowler 氏平衡㭘查法を施行して，两検查法の相互関俰について 調べた。これによつて少数例乍ら两湌查法に対する傾向 が比較され得ると思ら．この成績を一括表示すれば第 17 表の上うである。

\section{第 17 表 Fowler 氏严衡松査之本梌查} 成縝上の関倸
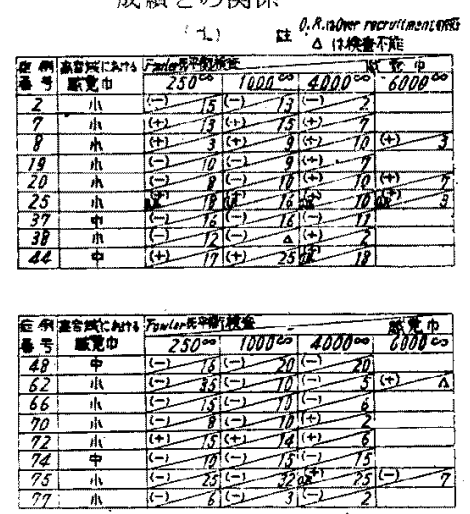

これを原因別炕みると，メニエール氏病の症例 7,8 は Fowler 氏法陽性で，本検查法の感敩幅は高音域で小で ある，症例 2 は両側同程度難聴のため，Fowler 氏法は 陰性であるが，高音域の感覚幅は小である。

音響性雚聴の症例 19,20は Fowler 氏法陽性で感覚 幅は高韵域で小である。

外傷珄難㯖の症例 25 は Fowler 氏法は over recruitment であり，高音域の感觉幅は小である（但し，両耳 同程度難聴例である)。

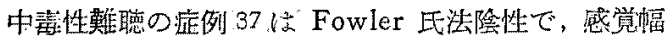
は中であり，症例 38 は Fowler 氏法陽性で，高音域の 感覚幅は小である。

中枢疾患患者の症例 44 は高音域で Fowler 氏法は over recruitment であり，4000のの高音域で感覚喀 は大である，症例 48 は Fowler 坆法除性で, 感覚幅は 4000ひ の高音域で犬である。

原因不明の是例 62，70，72 は Fowler 氏法陽性で，
感覚幅は高音域で小である。症例 66,74 Fowler 氏 法陰性で，感覚幅は中である。

㾏例 75 は 4000क で Fowler 氏法は over recruit. ment であるが，該当周波数の基本聴力耳の方が闇值が 低下していたつめに出現したるのと考光られる。しかし 6000め で Fowler 氏法は院性となり，他方感覚幅社 6000む に打いて小となつた。しかして Fowler 氏法陽 性の出現周波数之本检楂法の感覚幅小の出現状態は方法 が暴ると其に，必ずしも一致在及ない

症例 77 世 Fowler 氏法陰性であるが，耐側同程度の 難聡であり，感覚幅は高音域で小である。

以上の成績を総括すれば，

(1) Fowler 氏法陰性で感覚幅小のもの3 例は雨側同 程度難恥であり，䏇力差がなかつた：

（2）Fowler 氏法陰珄で，感賞愊中のものが2 例ある.

（3）Fowler 氏法陰性で，感営愊大のるのが中枢性疾 㭧にみられた。

（4）Fowler 氏法陽性で，感覚幅小のものが 8 例であ る.

（5）Fowler 氏法陽性で，感覚幅中及び大のるのは認 められない。

(6) over recruitment で, 感覚幅小のもの 2 例は軕 側同程度嚾聴である。

(7) over recruitment で，感喾幅大のるのが，中枢 性疾忠にみられた。

(8) over recruitment で, 感覚幅中のものは認めら れなかつた。

Fowler 氏現象の陽性火出る場合は，コルチ氐器の奖 化によるものとされており, 明らかルコルチ氏器病变と 考えられるむのに和ける本㛟查法の感党幅は小であるの で, Fowler 氏法陽性と, 感覚幅小の場合は同一病変の 反応であると考劣られる。

しかして，雨検查法は平行的であることが多く，本検

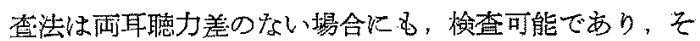
の発現状態によって, 病变部位の推定が可能である.

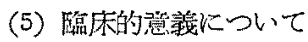

伝音系奞聴の感筧幅は殆えど中であるが，浸出性中耳 炎汇括いて，感敩幅が小となつた事は，内耳機能陣害の あるものは先基楚となるるのつ一つに中耳腔の炎症が 考えられるのである. 即ら組織腔に重大な障害を残す化

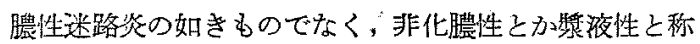
される Wolf のいう可逆性の内耳病变を著起した揚合 であると考兄れる。 
文献的にも，名大後藤教授(1951)，本杉，森山(1959) の報告がある。他方 Veckmans (1949)，河辺(1955)の 耳内筋障害によるむのであるらという説もあるが，横抹 (1954)は耳内笳摘除術前後の Recruitment 現象を調 ベて, その本態は内耳揤ちコルチ氏器ですると述べてい るのである。

感音系難聴の中, $x=エ-ル$ 氏病は凡て, 感觉幅小で あり，Fowler 氏法陽性である事からして，コルテ氏器 の病贺によるものと思考するのである，文献的にも*ニ エール氏病は内耳血行障害詋が有力であり，Dix, Hallpike, Hood (1948) はその病理的な 週程として，先ず コルギ氏器の毛細胞の病変をきたすものと信じて扣り， 本病による難聴では Recruitment 珼象の発現をみる と述へ，この説はその後，Lüsher，Ermani, Migind (1950), Edy, Williams (1951), Lundborg, Meycr (1952）その仙によつて認められているのである.

音響性難聴は全例が感党幅小であり，Fowler 氏法施 行例は Recruitment 陽性であり、コルジ氏器病变によ るものと推考するのである. 交献的にも形態学的に，古 くは Wittmack，吉井により，近年は其験的に Ruedi (1951)，名大後藤教授（1953），切替（1954），原回 (1956)，新井 (1958)，滰本 (1959)，吕の他幾多の士に

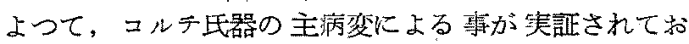
り，機能的には音響が個体の白得神経㙨能に 影響を与 え，次にその支配下の血管采障害をきたして遂にはコル ラ氏器の変性に宿る過程を強調する河田 (1954), 安達, 岩本, 吉岡 $(1956,1958)$, 山川, 久保 (1958) 等の血管 系障害説があり，共にコルチ氏器の病柗をきたす事を背 定している。

外傷性難㯖は感賞幅小のものと中のものとが半数宛を 占めている. Fowler 氏法施行例は recruitment 陽性 で，感覚幅小であり，コルチ氏器病变之考えられる．感 党幅中のものについては，頭部外傷による難聴が外傷の 受傷部位，外傷の受傷程度によってかなり異ってくる事 を考皃れば，その受傷が迷路に限局しないで，聴神経の損 傷，更に脳実貿の損傷等を同時に惹起する場合がある。 この場台，後迷路性の病变の成績は，中枢性疾患㭧者の 場合之同じく感覚幅は大乃至中になると考㝋られる。し かる時はコルキ氏器病变では感覚幅小となるだめ感覚幅 は迷路性と後迷路性との混合型，換言すればその中間值 の感敩幅中となる事が考爷られるのである。

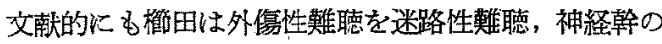
難㯖，中枢性難聴の 3 型に分類して括り，W.E. Grore

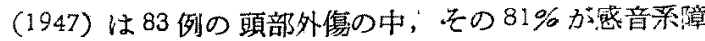
害又は混合型であると述べている，Recruitment 現象 の発現厄関しては, Recruitment 現象陽性説は M.

Salzmann (1950), Azzi (1651) 等であり，不定型説は 河村, 志井田 (1953), 河辺 (1955), 志村, 中島 (1959) 等があり，志村，中島け形部外傷後胎症の 150 名に，閔 值上聴力梌查の綜合判定から，伝音柔難聴は極めて少 く，主として感音系難聴であり，しか子後迷路性（中枢 性)障害を伴らものが少なくないと述へている。

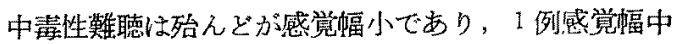
を悡め，Fowler E法施行例は陽性であるるのは感覚幅 小であり，陰性のものは感筧幅内である。

以上の成㺓から感賞幅小のものはコルチ氐器の病变に よるものと推考される. 感覚幅中のものは、ニルデ器 の病变と同時に又は二次的に中枢性にる病変の波及した むのと推考する。

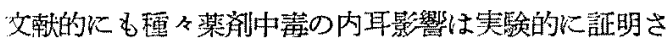
れて, 病理的には血行異常が起ると云う説及び兽神経並 に終末器官に退行变性が急激に現われるという説と2 説 がある。

本検查法ではストマイ難聴は感覚幅小, Fowler 氏法 陽性であつてコルチ氏器の病変と推考されるが，文献的 には Glovig, Fowler (1947) の中枢説及び Floveng, Hyden (1949), Berg (1951), Causse, Christensen, Hawkins, Lurie (1953) 等の末梢説の 2 説がある. 中村 (1957) は神経中枢及び内耳の組織化学的研究と蛆 牛電位に関する電気生理学的研究によつて，病変恃最初 内耳におこり，同時に中枢部にも一定の病变を䓌起寸る が，それは内耳よりの二次的病変である事を明らがし ている.

䇥性病性難聴は 2 耳共感覚幅小であり，コルテモ器の 主病変と推考される。

文献的に，河辺 (1955) も䓡性病後性難聴はコルチ民 器の病変を主体として, 聴神経炎も有すると述べてい る。

老人性難聴は感覚幅㤌殆んど中で1 例が小であり，感 覚幅小のものはュルチ氏器の主病変と推考され, 感覚幅 中のものは，最初コルチ氏器に病变をおこし，二次的に 喵神経さらに聴中枢へと病変波及して感覚幅が中となつ たか，聴神経のみの病変によるか不明である. 文献的に む古くは Saxen; 新しくは山川 (1957) の病理組織像偟

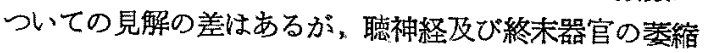
退行を認め，山川はその中でも細胞や繊維の単なる消失 
だけで，その消失した跡に組澈液があるのみで，䂬隐上 して見克，消笑した跡に細胞浸潤及び結合織の補莣を認 めると述べている。

低方 De-Bruine Altes (1944) は Fowler 氏現象は 発現しない上発婊以来々の説は認められて和り，Mau-

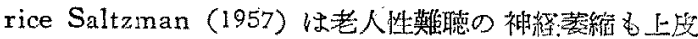

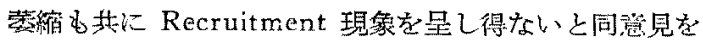
述べているが，上野（1958）は殆んど陰吽であるとして 陽性例の市る事家認め，村島 (1955) は Recruitment 現象の存在壱認め，小林 (1957) は老人性難聴の約 $30 \%$ K Recruitment 現象の発現があり，聴力障㐁部位を終 末感音器の变性に因るとし，難聴㷛自覚者江終末感音器 の変化が多く，自営渚沦中枢的要因を含むるのが多く， この变化は年令と共に買加すると述べている。

家族性難聴 3 耳の中，1 耳が感覚幅中であり，他の 2 耳は感喾幅大であり，感觉幅小のものは認められない所

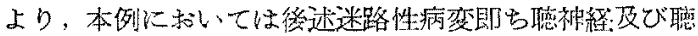
枢中の变化によるものと推考する。

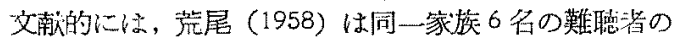

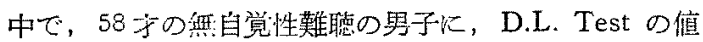
が小となり，Recruitment 現象の存在を認めている。

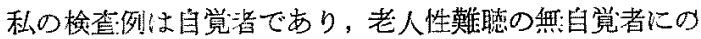
み感䁈幅は小であった事より推測すれば，あるいは家族

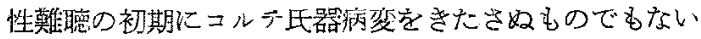
と思わ礼るも，老人性難㯖には感覚幅大のものはなく，

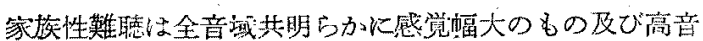
域の感営幅大のbのを認める事加ら，悡以後迷路性病变 に上るもの亡推考するものであるが，症例数も少い珰で あり，今後の研究汇壱つ所大である。

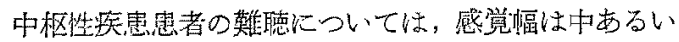
は大を認必，感覚幅の小のものは認められない，感筧幅 の大のものがあると云う事は後述迷路性病变即ち畦中框 あるいは悖神経の主病変と考えられ，Fowler 氏法施行 の1例は陰性であるが， over-recruitmentを呈した1

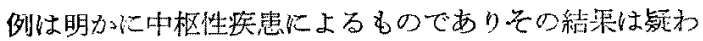
ᄂW.

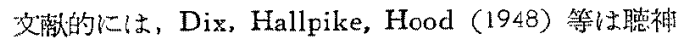

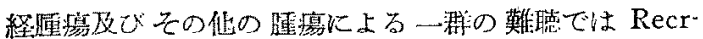
uitment 現象は発現せず，これは腫漟の圧迫による内

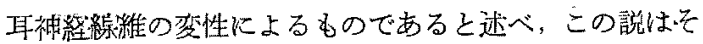
の後幾多の学者によつて認められるに至つている。

E.P. Fowler (1950) は Recruitment 現象を認め る聴神経腫缹の一例を挙げてこれに反駁し，輌び Dix，

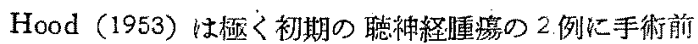
Recruitment 現象を呈したが，腫湯摘出術施行後には Recruitment 現象を認めない例報告して，聴神経腫

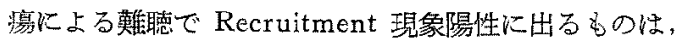

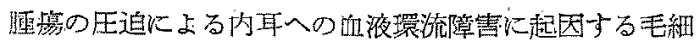
胞の变化に求好扔る。

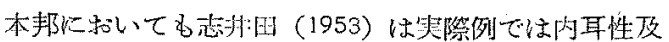
び中枢性の禹者の中間型とも云うべき場合が多くて，带

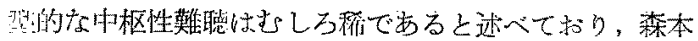

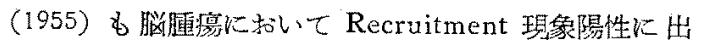
る洔は随伴する二次的内耳病变による結果であるうと云 い, 脳全体の動脈血行障害では内耳性難聴より後迷路 性難聴の方が起り易い事を示唆して, Recruitment 現 象のない事が，後迷路性難聴の特徴として举げられると 結えている。

斯くの期く腫瘍による難聴では原則的には Recruit-

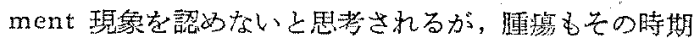

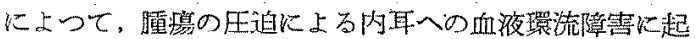
因与る毛細胞の病变によつて, Recruitment 現象茥 する場合もあり得ると思わ机る，

ともかく私の絰験例では, 高音域において, 感覚幅中

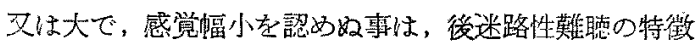
と解するものである。

次に原因不明の感音系難㯖について，前記原因の明ら かな内耳難聴の成積から，感覚幅によりてその病変部位 を推考寸る事ができる。即古，高音域に抹いて感觉蝠小 のものはコルデ氏器の主病変之考夏られ，70\%以上を占 めている，中音域に引䋨き高音域の感覚幅大のるのは中

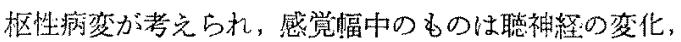
内取液の変化，コル方上器と聴中枢の同時変化文は二次 的変化等，障害部位についての局好彰断はほ心゙可能であ ると推考する。

\section{第 5 章 結 語}

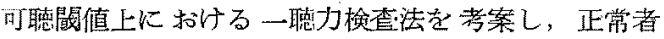

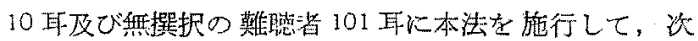
の結果起得た。

（1）正常者の感覮愊は，間值上 $20 \mathrm{db}$ の強さに战いて

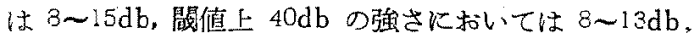
閾値上 $60 \mathrm{db}$ の強さに括いては 7 11db である. 以下

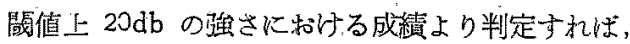

（2）炎症を伴方ない伝音系難㯖では，感覚幅は周波数 によって少し大もあるが中と推考する。

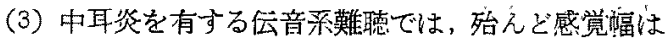


中であり（周波数によつては感覚幅は中乃至少し大であ る), 僅かに济出性中耳炎に感覚幅小の例外も認めたが， 骨導の延長を認めず，内耳の同時可逆的变化が推考され る。

（4）感音柔難聴では，メニエール氏病，音響性難聴，

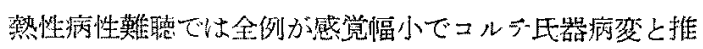
溚される。

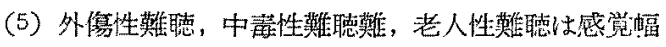
小のむの，中のもの上二者が認められ前者はュルラ此器 の病変に上るもの，後者は更に二炏的に後迷路性（聴福 経及び聴中枢）に病変が加わつたものと推考される。

（6）家族性難聴，中枢性難聴は感觉幅中叉は大で，感 覚幅小のものは認められないこの事より後迷路性病変 が推考される。

（7）原因不明の感音柔難㯖恃感覚幅が大，中，小の三 诸があり，感覚幅の発現状態からその陌害部位について 推考する事が可能である.

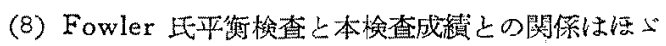

平行的であり，密倿な関傒のある事を知つた。

(1) Fowler 氏現象陽性の当のは，感覚幅は小であ るが，その発現周波数は必ずしる一致しなかつた。

(口) Fowler 氏現象陰性で, 感紝幅小のものは雨側 同程度難㯖の場合に文ら杂た。

（八）Fowler 氏現象陰性の中枢性疾患例及び over recruitment を呈した中枢性疾患例の感覚幅は大であつ た。

（9）以上の検查成績から本検查法の臨床的意意を炊の 如〈推考与る.

（1）感覚幅小のものはコルテ氏器の主病変と考えら れる。

（口）感覚幅中のものは聴神経の变化, 内耳滩の变化, コルチ和器と聴中枢の同時又に二次的变化等が考克られ る.

（八）感覚幅大のるのは䏇中枢に变化あるるのと考光 られる。

\section{第 2 編 䒠験 的 研究}

\section{第 1 章 緒言}

第 1 編に述べた臨床成緢上り本椮查法によつて感敩幅 の小であるものは、ォーデオグ フつ型から見ると，高音 急訟型及び高音低下型比多く，原因別からみると，メ二

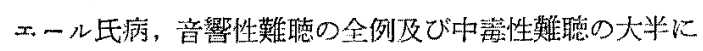

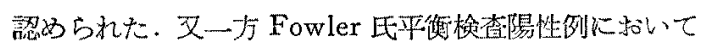
本検査法の感覚幅は小を示している。この䟢からしてコ

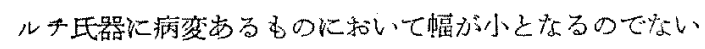
かと推察导れるに王つた。

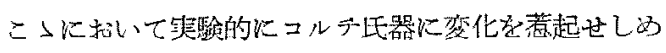
た場合に，感賞幅が小となるか否か索，猫及び人に放い て追及することによつて，然の検查法の襄付讨堂行い， それによつて本検查法の臨床的価値を明らかにせんとし た。

\section{第2 章 動物 (猫) 実験}

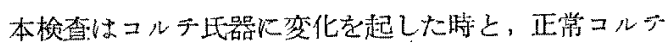

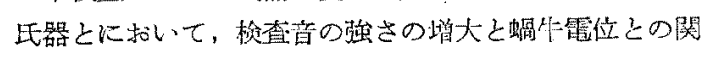

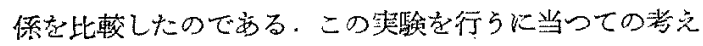

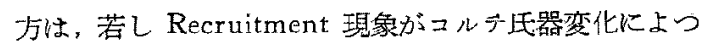
て現われるものであるならば，病的コルケ氐器の際は换 查音の增大によつて，螖牛電位が急炕大となつて現机て もよいと考えたのである。

\section{第 1 節 研究村料及び研恎方法}

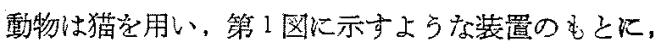

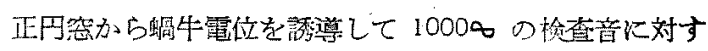

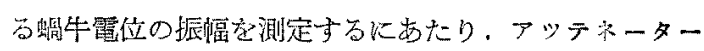

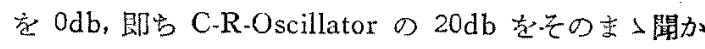
せた時の握幅虑測定し，次いで $5 \mathrm{db}$ 宛の減衰を行いつ つとの都度蜩牛電位の振幅を测定したのである。

しかしてこの際 Noiselevel と判定困難な所で打切つ た。

\section{第 1 図実験装置}

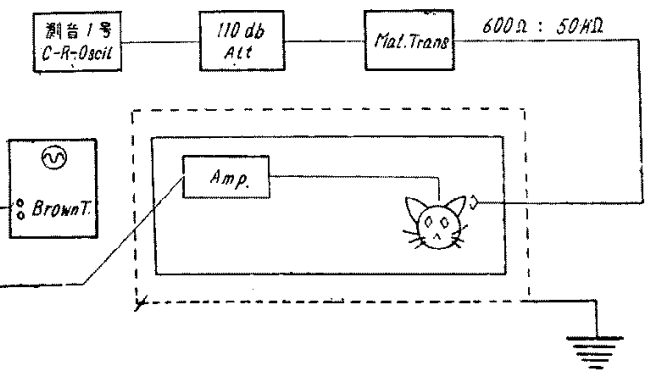

正常猫に 1000 一, $90 \mathrm{db}$ の䆨を30 分，60分，120分 と作用せしめたものを病的耳として，同㥞に測定した。 


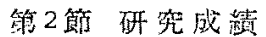

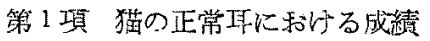

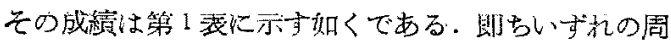

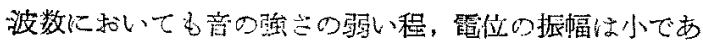
る.

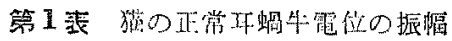

\begin{tabular}{|c|c|c|c|}
\hline \multirow{2}{*}{ 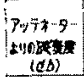 } & F & 活 & * \\
\hline & 2500 & $1000^{60}$ & $4000^{\circ}$ \\
\hline 0 & $50^{2 x a 9}$ & 5000 & $60^{2 / 2}$ \\
\hline 5 & 27 & 30 & 50 \\
\hline 10 & 20 & 24 & 34 \\
\hline 15 & 16 & 20 & 20 \\
\hline 20 & \begin{tabular}{|l|} 
Molez \\
Leral \\
\end{tabular} & 12 & 13 \\
\hline 26 & & 4 & 9 \\
\hline
\end{tabular}

\begin{tabular}{|c|c|c|c|}
\hline \multicolumn{3}{|c|}{ 桡例 I } & \multirow[b]{2}{*}{5} \\
\hline \multirow{2}{*}{ 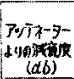 } & I 19 & Dh & \\
\hline & $250^{\circ}$ & $1000^{5}$ & $1000^{\circ}$ \\
\hline 0 & $60^{\mathrm{mm}}$ & $10^{\sin / 2}$ & $60^{\circ}$ \\
\hline 5 & 40 & 32 & 38 \\
\hline 10 & 34 & 24 & 23 \\
\hline 15 & 26 & 20 & 20 \\
\hline 20 & 20 & 16 & 75 \\
\hline 25 & $\begin{array}{l}\text { Moise } \\
\text { Lerel }\end{array}$ & 14 & 11 \\
\hline
\end{tabular}

第 2 項 病的耳 0 成綪:

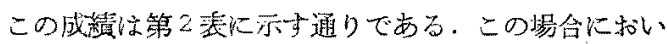
ても音の強さの弱い程，電泣の振幅は小である。

第 2 瘏的平の螖牛電位の慓
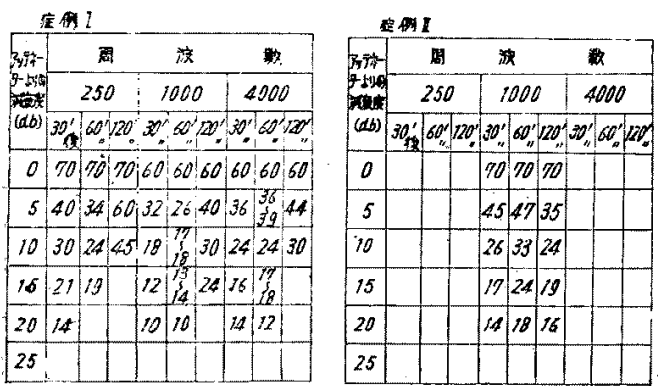

第3項 本節の小括

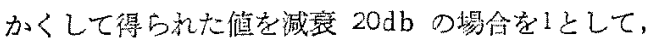
化の娍受の場合の比率を算出すれば第了長に示すようで 放る。

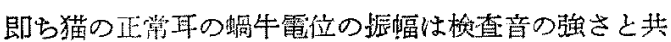
炕大となるわ゙，その增大率は強さに比例している。

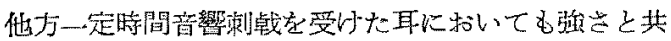
に振幅は大となるが，強さに比例せずして念激に大とな るところがある。

20000 ○姝に減衰 $5 \mathrm{db}$ と $10 \mathrm{db}$ の間及び減衰 $10 \mathrm{db}$

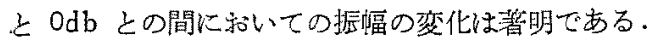

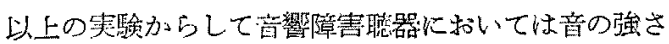
を增大する㭙，正常耳上りは非常に大きく感じ得られる

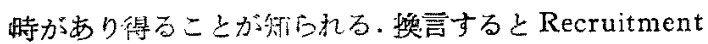

第 3 表 音の强さ之期牛電位の振湢との网倸 症例 $I$

\begin{tabular}{|c|c|c|c|c|}
\hline \multirow{2}{*}{ 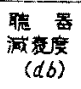 } & \multirow{2}{*}{ 正常 } & \multicolumn{3}{|c|}{ 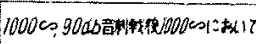 } \\
\hline & & $30^{\prime}$ & $60^{\prime}$ & $120^{\prime}$ \\
\hline-20 & 1. & I. & 1. & l, \\
\hline-15 & 1.66 & 1.20 & 1.30 & 2.40 \\
\hline-10 & 2.00 & 1.80 & 1.80 & 3.80 \\
\hline-5 & 2.50 & 3.20 & 2.60 & 4.00 \\
\hline 0 & 4.16 & 6.00 & 6.00 & 6.00 \\
\hline
\end{tabular}

䏠 例 II

\begin{tabular}{|c|c|c|c|c|}
\hline \multirow{2}{*}{ 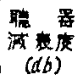 } & \multirow{2}{*}{ 正 常 } & \multicolumn{3}{|c|}{ 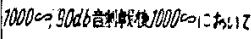 } \\
\hline & & $30^{\prime}$ & $60^{\prime}$ & $120^{\prime}$ \\
\hline-20 & . & 1. & t. & 1. \\
\hline-15 & 1.25 & 7.21 & 1.33 & 1.18 \\
\hline-10 & 1.5 & 1.85 & 1.80 & 1.50 \\
\hline-5 & 2.0 & $3.2 \%$ & 2.60 & 2.10 \\
\hline 0 & 3.7 & 5.00 & 3.88 & 4.37 \\
\hline
\end{tabular}

現象が起り得ることを利るのである。

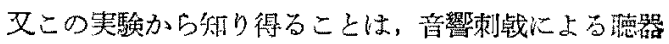
变化がコルゲ氏器にあるので， Recruitment 現象はコ

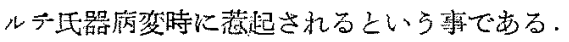

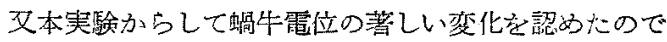
Recruitment 現象は聴中枢に拀いての変比によるので ない事を咸つた。

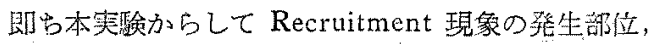
並に・その本態孛明らかにし得たのである。

\section{第3章 人における実釦}

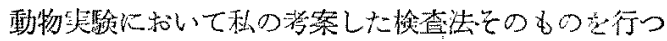

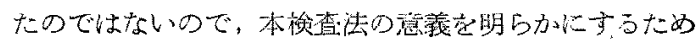
本研究を行つた。

第 1 節 研究刘象及び研究方法

研究対象ししては第1編の正常聴力者の3 台につい

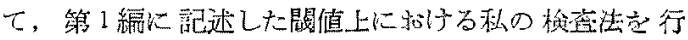
い，その後 $10003 ， 90 \mathrm{db}$ の音を30 分間珤取せしめた

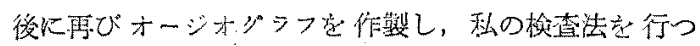
た。

第2 筑 磔究成滥

正常耳について閶值上の私の梌查法を施行した偻，艺

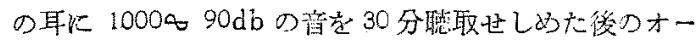
ジオダンフは高音部がある程甡の低下を示した。この状

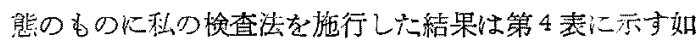
くである. 


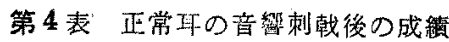

\begin{tabular}{|c|c|c|c|c|c|c|c|c|c|c|}
\hline 用狄 & & 250 & 500 & 1000 & 1500 & 2000 & 3000 & 4000 & 6000 & 8000 \\
\hline & 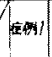 & $\frac{18}{12}$ & $\frac{14}{11}$ & $\frac{14}{15}$ & $\frac{23}{9}$ & $\frac{25}{8}$ & $\frac{22}{10}$ & $\frac{30}{5}$ & $\frac{35}{5}$ & $\frac{33}{6}$ \\
\hline & tent & $\frac{20}{14}$ & $\frac{19}{15}$ & $\frac{16}{14}$ & $\frac{20}{14}$ & $\frac{20}{13}$ & $\frac{15}{15}$ & $\frac{78}{12}$ & $\frac{25}{8}$ & $\frac{35}{5}$ \\
\hline 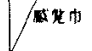 & EN, & $\frac{22}{15}$ & $\frac{20}{13}$ & $\frac{15}{12}$ & $\frac{18}{13}$ & $\frac{23}{8}$ & $\frac{22}{10}$ & $\frac{15}{13}$ & $\frac{32}{6}$ & $\frac{308}{5}$ \\
\hline
\end{tabular}

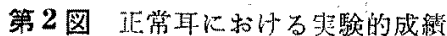
店例 AM-ISホーデホッーター㙂官检骖国 正整职党巾

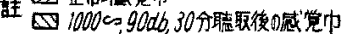

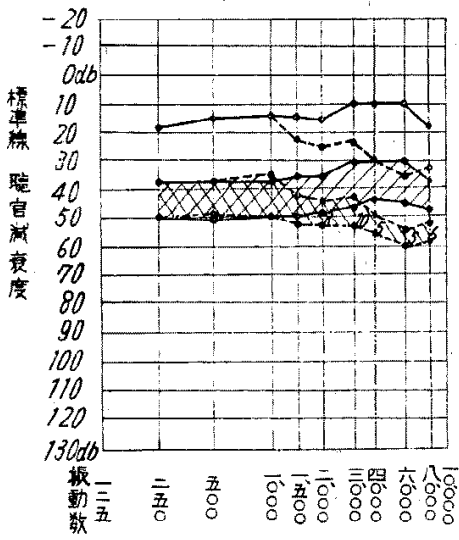

これによると第2図に示すよらに，去響によつて低下 した离音部に和いて閶值上の感覚幅が明らかに小となつ ている。これに対し但下しない周波数の部では感覚幅は 正学值である.

即らこの研究からして音翼によつてコルテ氏器变化を

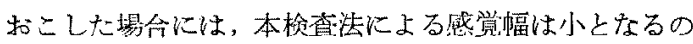
である。

\section{第4章 本編の総括並に考按}

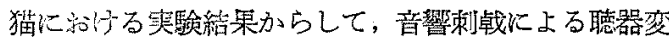
化がニルギ比器にあるので, Recruitment 現象はコル

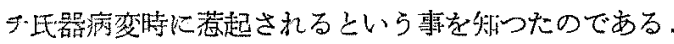

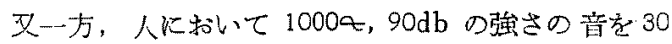

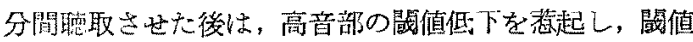

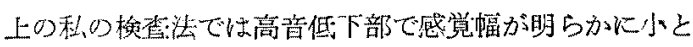
なつている.

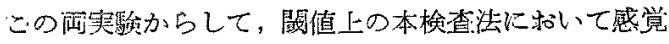

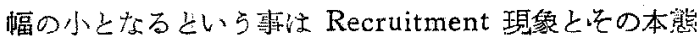
を一にしているものであり，その本態はコルテ氏器の変 化であることを知つた。

Davis, Ruedi and Furrer, poppoff 等㤝動物実験に

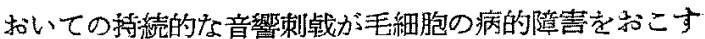
と述べており，1957 年武山は家鬼に音澼刺战を与えた

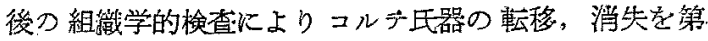
一，第二廷転に認めている。

1958 年高會は螖牛反応による聴覚根学々, Recruitment 現象について，音楒刺㦸により内耳機能に Recruitment 現象が出現する霞を教告している。

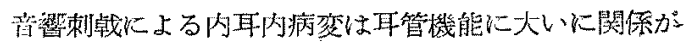

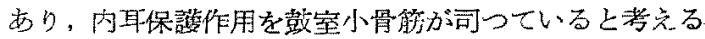
沢田，江崎（1951 年）, 落会，田中（1952年），芜本， 桖谷 (1953年)，河迅 (1955年)，山本 (1956年)，河 日（1959年）等がある。河辺は Recruitment 現象の

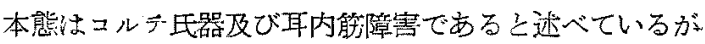
倳判（1954年）は河辺の研究方法を网いて，慢性穿孔 性中耳然㭧者 48 名に術前後の Differnece Limen Test によつて Recruitment の発現状態を調心゙, Recruitment 現象陽性者の耳内螎摘除術により Recruitment 不

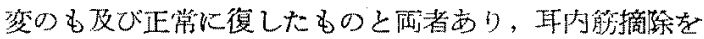
しないものでも Recruitment 現象は陰性となつたもの があり，耳内筋障害に上るるのもあるが，资症による内 耳の一時的障害を教慮しなければならないと述べて，

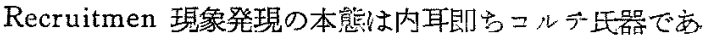
る事を認めている。

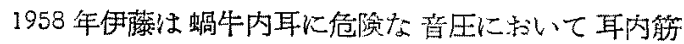
の音響減弱效果は低，中音域において著しく，高音炕持

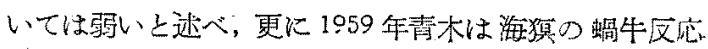

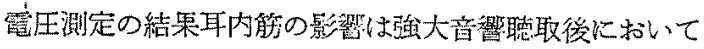
僅かに $1 \mathrm{db}$ 前後の低下で，それ以上の低下は蛤牛の疲

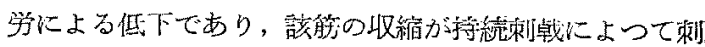
战直後と殆九ど同様な作用を常に保つているとしても，

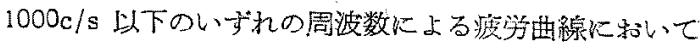

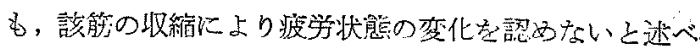
ている。

同年滝本はコルテ氏器細胞の核酸に屡する研究におい

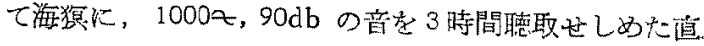
後に断㩆して得た内耳のコルジ氏器において，外有も細 胞核は䈹小し，核内構造不明瞪及び Deiter 細胞烧の

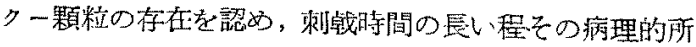
思は変化していると述べ Lawrence a. Yantis, Beck

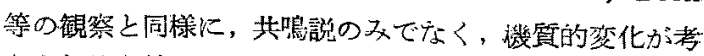
えられると結んでいる。

以上の如く音響性刺载は，コルデ氏器の病変を惹起す

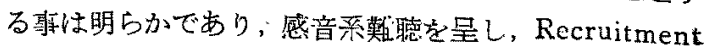


現象陽性となる。耳内筋障哣は Recruitment 現象の発 现火関して，一因子となりうる牙もあるが，本態的には コルキ氏器病変によるものである。

\section{第 5 草 結論}

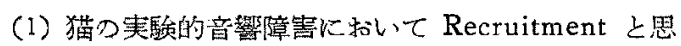
われる現象がおこりらる專を和つた。

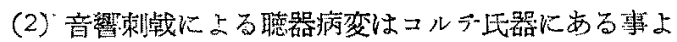
り，Recruitment 現象はコルデ氏器府変時に㴔起され \%.

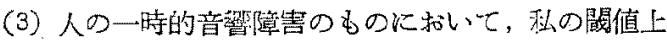
の検查を行つたところ感覚幅が狭く（小なつた。

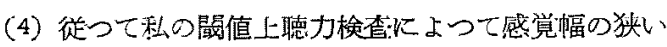
(小) のは Recruitment の存在が考えられ，コルげ 器に主病変があるものである。

\section{第6章 全編の綕括，考按並に結語}

第 1節 全編の総括, 考按

閔值上の一㯰力検省を考案し，101耳の難聴に施行し

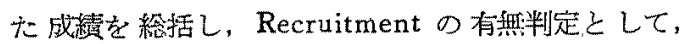
Fowler 氏平衡梌套を施行，刘比すると共に，動物及び 正常聴力諧の夷験的観察を行つて，本検查法が難聴の病 変部位揨断上に上める意義について梌討を試みた。

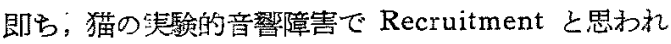

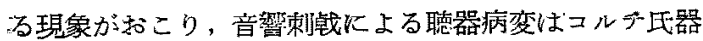
にある事から， Recruitment 現象はコルテ哭器病変時

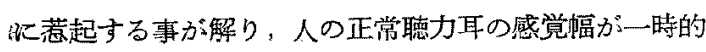
意琶障害を起さ中る事に上つて正常幅（中）から高音域 の聴力低下部では縮少して小を呈した事からして，本検 查法の感覚輻小のbのは，Recruitment の存在が考光 られ、コルテ氏器の主病变であると推考する。

“伝音系難聴では原則的には感覚幅は中であり，極く䓬 カかの例外西羿めたが骨尊の延長を認めめため，内耳への 一炎鿊波及と解した。

感音柔難聴では，聴力低下の高音域の感覚幅小のもの が我然多く，その66\%を占めた。この中に：コルキ氏

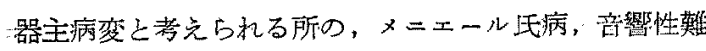
聴は全例が感覚幅小であつた。

感覚幅大のbのは，中枢性疾虫及び家娭性難聴に友ら れた。

感覚幅中の \&のは，全周波数の 感覚幅の 発現状態か

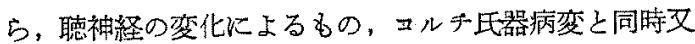
は二次的に聴中枢に病変のあるすの，内耳液の変化によ るあの等がが推考されんた。

以上の成績を得た発病原因の明らかな個々の疾患につ
いては，第1編において総括，検討を北えたのでこつで

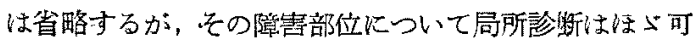
能である。

では Recruitment 現象の発現機転について步理学 的, 病理学的な程合の説方饬るが, FowlerはLorente de no が德神経線維は数個の赥胞に分布しているとい う解剖所晃に立朋して説明していることを述べている。

これによると本琪象が成立するといら隶は椮查音の強 さが增加した锡合にとの不完全な神経芳配装置にむ拘ら

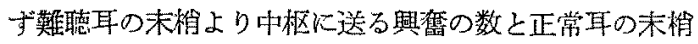

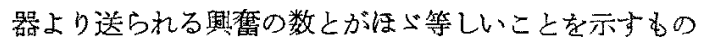
である。しかしてすべての神経はとの終末突起に扣いて

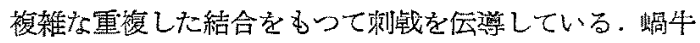

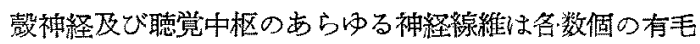
細胞と結合し，各有毛細胞は数本の神経楾維と結合して いる，そして音の強弱は有毛絉胞より発する個々の神経

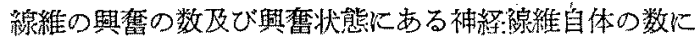
よつて洪定されるのである。㐜㦸が弱い場合には末梢器 の少数の有毛細胞のみが活動状態に入つて篮か心神経腺 維が興䳽してくるにすぎないが，刺㦸が增すと有毛細 胞, 神線综維共興奮を起し活動を初めそのため算位時閒 に数多くの刺戟を中枢に送るようになる。として束钱の

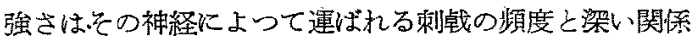
を有し, 神経湶維の興稫の頻度が刺㦸の数に密接に比例 するものであれば，Fowler 氏現象発現に対する解決忧 不可能であるが，神経線維は一定限度以上の頙度の刺暲

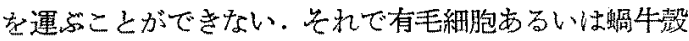

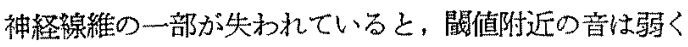
より聞えないが，強い音恃牫つている神経線維定極度の 強さに迄刺㦸しそのため脳皮望に難聴耳から每秒当り正 常耳からと同数の剌战を受けとるのである，故に强い音 刺皒の場合には患耳において子正常耳に近い大きさ聴 えるのであるというのである。

及 Kobrak はコルデ氏器の感覚細胞は色々の強さの 刺㦸见適応するものである。外毛細胞ではたら゙ 30〜40

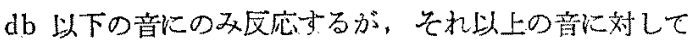
は内毛細胞が機能を行ら。

Recruitment 現象が存在する場合には外毛細胞は障 㫪を起しているが，その埸合内毛細胞はなお正常の機能

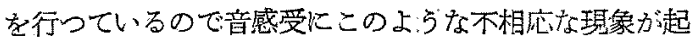
るのであるとしている。

これ対し Veckmansは1949年. Recruitment 現 象は本質的には生理的現象であつて, Recruitment 現 


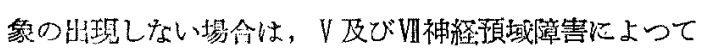

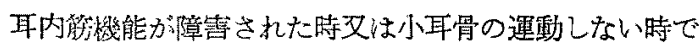

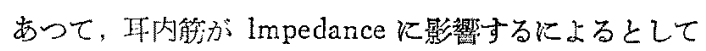
いる.

こ就反し Pirodde は1950年 Recruitment 現象は 中耳機能儿は梨関釈である之称えている。

1950 年 Mygind は本現象はコルデ裳の障書上密接

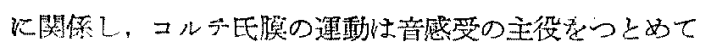

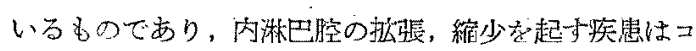
ルト暤索变形する。そして Recruitment 現象が存在

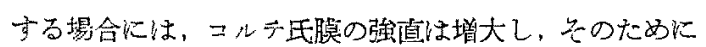
感覚細胞かららり多くの剌㦸が運ばれるたるに不相応な 認知か゚起るのであるとしている。

1950年 A. Tumarkin は dual pattern 説で本現象

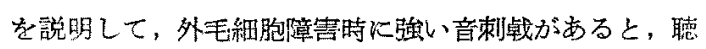
神経の全與奮は正常時に近似するし，不完全に聞えた胿 においても，中枢で正しく判断するのである。

1951 年 Borghiesan は Recruitment 現象を内淋巴 の量的並に質的変化で説明して，内淋巴王の上界はュル チ氏膜を扁平化しここれよつてコルジ氏器に王迫せら れる、その結果として毛細胞の毛はコルテ氏腹内に没す るので振動が哥くなる。しかし強さが大となる時には， このような毛細胞の刺㦸の增加率は急に大となつて、こ こに Recruitment 現舜が生ずる.しかして毛細胞の過 敏なことが本現象を完成するに役立つて, 時にはOverrecruitment の現㙏を起すのであると.

1954 年志扑田は over Recruitment (逆ファッフーE

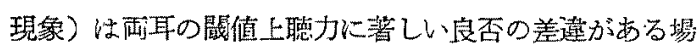
合には，最小可咕閾值が同一レベルであつても，これに 峝耳性大さ平衡検查:を実施して見ると balance linie は

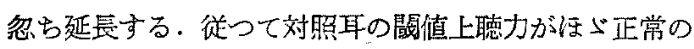
場合には，逆フアゥラーの成立は該侧鼠值上聴力の異常

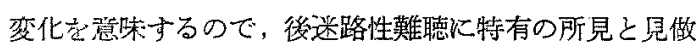
๖ことができる，但し，両耳性大さ平衡検查の成瀆は禹 耳難恥型の組合也で左右され易いので，この逆フアゥラ 一現象の成立を好つて值らに中枢性難聴之断定すること

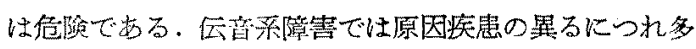
少の周波数差はあるが，低音域より高音域に亘る全悪力

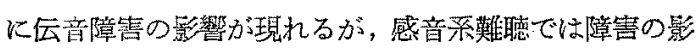
響が限局した周没数域に現れる場合，あるいい低音域聴

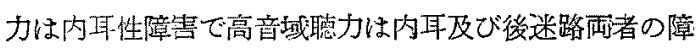

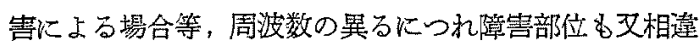
し得るのであると述べている。
河辺 (1955) は Fowler 旦平峢検楚及び D.L. Test を施行して，慢性中耳化膿症にも Recruitment 現象灻 呈するもの>ある事から，本琵缭発現の本態はコルチ氏 器及び中耳倿障害であると述べている。

以上述へたたこれ等の説明は，咕営説により，及は臨床

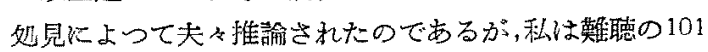

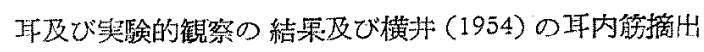

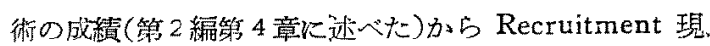

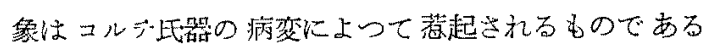
(本㛟查法の感覚幅はこの場合小である)，と思考する。

\section{第2 節 結 語}

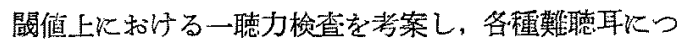
いて検語すると共に, 实験的研究によつて本検查法の本 態を追求して，次の結果を得た。

（1）本検查法の感覚腷は大，中，小の三者に分れる事 它知公。

（2）感賞幅小のものは, Fowler 民平衡検查陽性例に

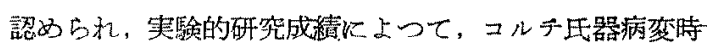
に著起されるものと推测される。

（3）感覚幅大のbのは，中枢性疾患及び家族性難恶に， みられ，聴中枢に病変のあるものと考えられる。

(4) 感覚幅中のbのは，Fowler E平衡㛟查除性であ り，锶神絰の主病変，コルチ民器と聴中枢の同時爻は二 次的变化, 内耳液疾患, 伝音亲障害等が考えられる.

(5) 本検查法によつて, 感音系難聴の障害部位の局所 䛦断が可能でする:

（6）本检登法性 Fowler 氏平衡検查之暴り，两耳德 力同程度のものでる行い得られ，且つ片側宛検查し得 万.

\section{主 要 文 献}

1) Bekesy, G.V.: Acta. Oto-Laryng. 35: 411 422, 1947. 2) Dix, M.R. Hallpike, C.S., Hood, J.D.: J. Laryng. and Otol $62: 671,1948$. 3) De-BruineAltes: Acta Otolary. Vol. 37, Nr. 5, 1649. 4) Hallpike, Hood: Proc. Roy. Soe. Med. Vol. 42, Nr. 7, 1949. 5) Dens, Naunton: J. Larngl. Otoll

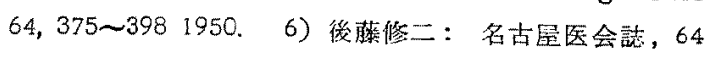
巻, 2 号, 1950. 7) Lüscher: Proc. Roy. Soc. Med. 43: 1116, 1950. 8) Lüscher: Bull, Schweiz, akad. Med. Wiss. 6: $1 ; 177,1950.99)$ 田: 日本耳奥会 報，53替，5号，16, 1950 。 audiol. Prat. Nr 2, 21, 1951. Laryngoscope. 61 : 400, 1951. 10) A. Azzi: Riv. 11) Eby. Williams: 12) Glorig. Washi- 
ngton.: Annols of Otolog. Rhinolg. Rarnyngl. 60: 327,1951１3）後菻修二：脳神経領域，11 册，1951. 14）後滕修二：医学，10巻，3号, 1951. 15) 切 替一郎：聼賞桱查法，前庭迷路穖能检查法，1951,11。

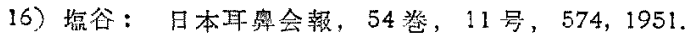

17) Berg: Acta Otolaryng Suppel 97: 1951.

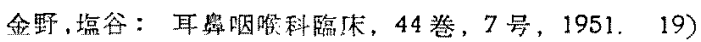

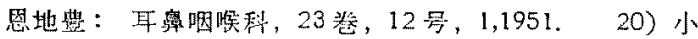

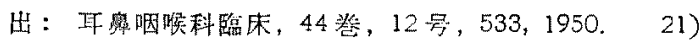
Lüscher, Zwislocki: J. Larngl. a. Otol. 65: 187, 1951. 22) Ruedi: Annals. O.L.R. 993, Nr. 4,

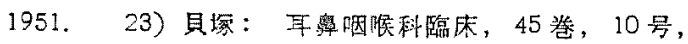
439，1952，24）志井田守：耳舆咽喉科，24替，11

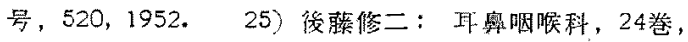
11 号, 13,1952,26) 田中敬一：日本耳解会報，55

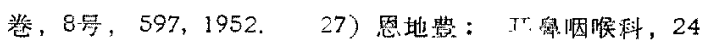

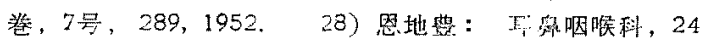

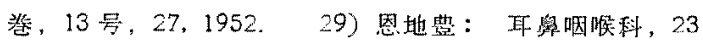
巻，12号，1，1951.30) 森本正紀：新鼬医学会雑誌, 66 巻, 9喿, 525, 1952. 31) Lundborg: Acta Otol. Larngl. Supp 99, $1952 . \quad 32)$ Reger: Annals of O.R.L. Vol. 61: 810,1952. 33) 塩谷: 日本耳粗会

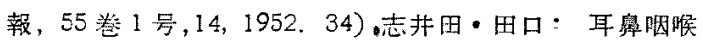
科，25 潦，13 号，837，1953、35) 志井田守: 耳奥咽 喉科，25 洗，9号，419，1953，36) 志井四守：耳鼻 咽喉科，25巻，13号，1，1953，37）志井田守：耳舆 咽喉科臨床，46巻，3号，110，1953，38）志排田守:

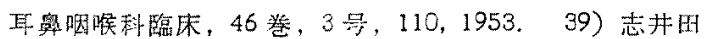

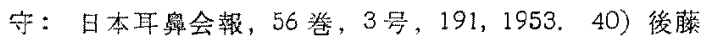
修二：奞聴の䛦断之沿療，1953，41) 後藤修二：耳

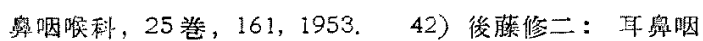
噍科, 25 巻, 311, 1953. 43) Dix. M.R., Hood. J.D.: The Journal of laryngl. Vol. LXVII. Nr. 6：340, 1953. 44) 切替一郎：日本音響学会誌, 10 巻, 2 号，110，1954.45) 志汼田守: 新湶医学雑誌, 68 巻, 11 号, 987, 1954.46) 原田筑紫：斥重と臨

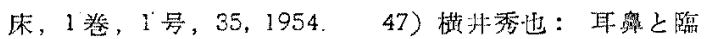

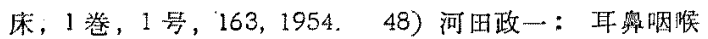
科, 26, 巻, 575, 1954. 49) Hirsh, Taunopalva, Allan goodman: A.M.A. Arch of Otolary, 60:525 $\sim 540$, 1954. 50) Shuji Goto: A.M.A. Archives of Oto Laryngology, Vol. 60, 342 349,1954 . 51) 村亶二郎：日本耳留会報，58巻，10号，1172，1955. 52）三宅弘：日本耳尖会報，58尞，11号，1331，1955.

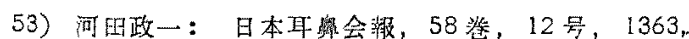

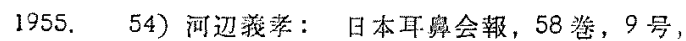
971 ，1955.55) 久木元正延：耳率咽喉科卧床，48巻，

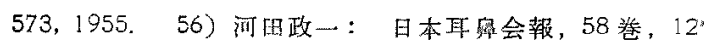

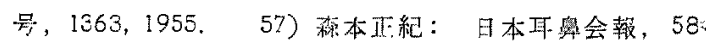

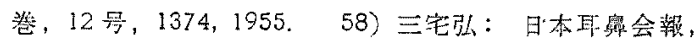
58 恣, 11 号, 1331, 1955. 59) Leroyd. Hedgecock, Rochester, Minn: A.M.A. Arch of Otolary. 62: 515 527, 1955. 60) Phillip A. Nautis ann Arbar Mich: A.M.A. Arch. of Oto. 62: 625 631, 1955. 61) Scott. N. Reger C.M. Kos, lowacity Jowa: Annals of Oto. Rhino and Lary $61: 810 \sim 823,1952$. 62) 立朴孝：耳骨咽诶科，27卷，293,1956. 63) 立

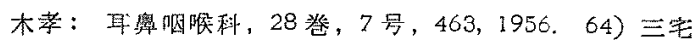

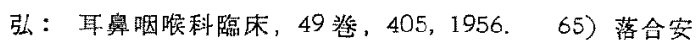

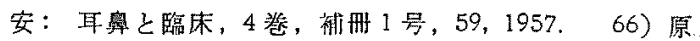
田筑紫：日本䎲奥会報，59巻，10号，1717，1956。

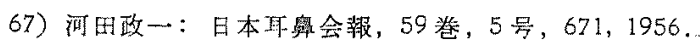

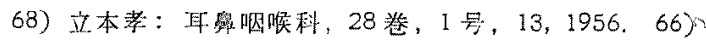

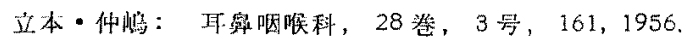

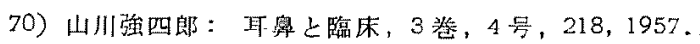
71) 中村文崔：耳舁亡臨床3巻，4号，227，1957。72)

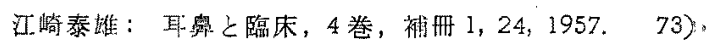
Hallpike. Hood: Re de Larngl. etc. Suppl. May. 220, 1951. 74) Hood: Excerpta Media Vol. 4, 298, 1951，75）小林恒久: 日本耳率会報, 61 巻, 1 ? 둑，163，1958.76）久保沿一：日本耳哞会報，61巻. 6号，948，1958，77) 吉岡勝行：耳舆之臨床，4巻，補 冊 3，1958，78）洗尾稳他，二名：工率咽喉利展望， I 巻, 3号, 393,1958.79) 本杉雅英：耳奥咽喉科，31

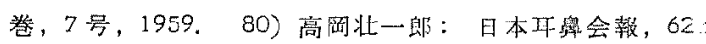
巻, 1号, 134, 1959.81) 河由政一：日本耳舆会報, 62 楚, 7 号, 1667, 1959.

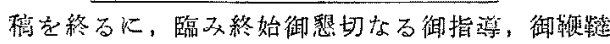
を睗り，且つ本椧文の御校閲を賜りたる恩師，名古

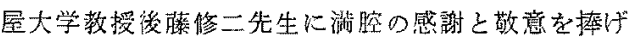
るものである。

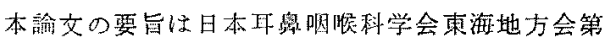
126 回例会(炤 26.6.23)，同地方会第 128 回例会(昭 27.1 .27 ), 同地力会第 129 回例会 (昭 27.3.30) K抹い て大笔表したものであり，且日本耳禹咽喉科学会 第 53 回総会の宿題赫告中 (炤 27.5.4) に後藤教授に

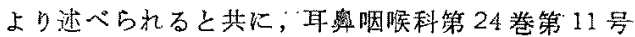
(昭 27.11.20 発行) 区び The A.M.A. Archives of. Otolaryngy Vol. 60 (1954 年) 洞教授によってと の概要を揭葴されたものである。

（原栜到着二昭和 35.2.16日） 